\title{
When Students Design University: a Case Study of Creative Interdisciplinarity between Design Thinking and Humanities
}

https://doi.org/10.1515/edu-2019-0002

received February 28, 2018; accepted July 12, 2019.

\begin{abstract}
This paper addresses the issue of how to enhance student participation in university governance. This issue is approached by taking into account the growing pressures of the European Commission's modernization agenda on the educational policies of the European Higher Education Area, and by focusing on the way these pressures affect students' conceptions of themselves and of the mission of higher education. The thesis presented in this paper is that design thinking and the humanities share a common epistemological core that enables them, if applied in educational settings, to play a major role in fostering students' trust in their governance skills and in their ability to influence educational policies through a creative mindset and a deeper comprehension of the stakes in present-day higher education. An experimental workshop combining design thinking with the humanities
\end{abstract}

1 Her acknowledgements are due to Andrea A. Gasparini for introducing her into design thinking and for his passionate contribution to the project, to Rick Szostak for his accurate and inspiring feedback on the theoretical sections of the article, to Manja Klemenčič for her helpful suggestions on how to frame further research on student agency on account of Europe 2020, to Giovanna Carloni for her insightful comments and all the conversations, and to Carolyn Burke, Lorena Marchetti, Betsy Pontellini, Clelia Boscolo, Cristina Pierantozzi and Guido Mililotti for their linguistic and IT advise. Last but not least, many thanks to the anonymous reviewers of this article, to the faculty members who took part in the workshop, and to the students, a source of constant inspiration. Uniurb and UiO sponsored the workshop. Alessandra Molinari authored all sections of this article; the whole section 4 (with its subsections) and sections 5.1., 5.2 and 5.3 (with their subsections) were co-authored with Andrea A. Gasparini.

2 andreg@ifi.uio.no.

*Corresponding author: Alessandra Molinari, Università degli Studi di Urbino "Carlo Bo", DISCUI - Palazzo Petrangolini, Piazza Rinascimento, 7, 61029, Urbino (PU),Italy, E-mail: alessandra.molinari@uniurb.it Andrea Alessandro Gasparini, Department of Informatics, University of Oslo, N-0373 OSLO, Norway and with the constructivist approach of student-centered learning was held within a course in a humanities bachelor program on the basis of a heuristic framework developed through an interdisciplinary research process. This process was conducted according to the principles of design and hermeneutics. The outcomes of the workshop in terms of the participants' enhanced self-confidence and decisional skills validate the thesis of this study.

Keywords: European Higher Education Area, student participation in university governance, student agency, student-centered learning, interdisciplinary research process.

\section{Introduction}

The case presented in this paper is an experimental design thinking (DT) workshop for humanities students which took place at the University of Urbino (Uniurb) within the Foreign Languages and Cultures bachelor degree program in Spring 2018. The workshop was designed to investigate the issue of how to promote two main areas of student democratic participation in higher education (HE): student-centered learning (SCL) and student participation in university governance. This issue is being debated by all actors involved in present-day European higher education (HE): scholars of learning sciences and education theory, student representative unions, and institutional policy-makers within the European Higher Education Area (EHEA). This debate is being led on the background of two diverging visions of $\mathrm{HE}$ and of the role of students in it: the vision of $\mathrm{HE}$ as a common good with multiple individual and social aims in a democratic society, and that of HE as a service-provision for the European job market in view of Europe's economic competitiveness on a global scale. In this perspective, students are thus seen respectively as proactive contributors to the common educational good 
and as consumers of an educational service provided to them.

Since EHEA was established in 1999, the Ministries for Education and Research in the EHEA have committed, at least on a formal level, to the first vision of HE. However, in the last two decades, the European Commission, itself participating in EHEA strategy-making, has increasingly pressed upon the national governments towards a modernization agenda and a managerial turn in HE.

The issue of SCL and student participation in university governance takes on a different meaning according to which of these visions predominates in a HE institution and government policy. Since we commit ourselves to the first vision, we decided to engage in a research project to foster students' self-awareness of their substantial role in HE as proactive learners and participants in university governance on the horizon of their adult contribution to democratic citizenship. We also aimed to investigate the reasons for a decreasing trend in student participation within the EHEA in the last few years, as well as to propose a means to counterbalance such a trend. Accordingly, we decided to design this workshop to respond to one emerging question: can DT foster SCL and student participation in university governance, and if this is the case, how?

The thesis underlying this question and the present research project is that DT can substantially foster SCL and student participation in university governance, especially if it integrates some fundamental insights from the humanities. An SLC approach linking DT with some fundamentals from the humanities as proposed in the present paper can help students to become more confident in their learning and governing skills and to better comprehend the stakes in present-day HE. Most importantly, such a joint approach can motivate students to take a position, that is, to proactively commit to their own vision of $\mathrm{HE}$ and to the role they want to play in it.

The research project was pursued as follows. The first phase was dedicated to frame the issue of presentday SCL and students' democratic participation in HE within the EHEA, and to assess the state of student participation at Uniurb. In this phase, we also identified a scholarly discourse (e.g. Klemenčič, 2012) viewing SCL and student participation in university governance as two phenomena intrinsically linked with each other within an overarching conception of student democratic participation in HE. By adhering to this discourse, we then focused on Uniurb: on its commitment to the EHEA founding principles, and on the state of SCL and of student participation in the governance of this university. In a second phase, we were concerned with contextualizing our main question into the educational environment of the Uniurb bachelor students to be involved in the workshop. The bachelor course we chose to host the workshop was one Germanic Philology course led by the Uniurb-based author of this paper. This philology course was designed by adhering to the didactic aims set by the SCL-based Dublin Descriptors (DDs) for the bachelor level. Thus, a suitable didactic environment was provided in which the experimental workshop might be embedded. Now the workshop itself had to be designed in order to respond to the question whether DT can foster SCL and student participation in university governance, and thus validate the thesis that DT can substantially succeed in this if it integrates some fundamental insights from the humanities.

As a starting point for the workshop design, we had to develop an interdisciplinary heuristic framework that should assess the mutual epistemological compatibility between DT and the humanities (philology). We built this interdisciplinary framework on the basis of Rick Szostak's research works on disciplinarity, interdisciplinarity, and his understanding of interdisciplinary research as a creative design process. From the third phase of the research project on, we relied closely on Szostak's (2017) description of the creation steps in interdisciplinary research. Accordingly, we assessed the disciplinary status of DT and philology to identify both their specific differences and their bridging points: the latter make up a substantial common epistemological core. We then filtered out of this common epistemological core three features that might be embedded in the constructivist backbone of the DDs to create the interdisciplinary heuristic framework for the research question to be investigated through the workshop. These features shared by DT and philology are empathy, creativity, and an overarching discourse on utilitarian and non-utilitarian views of the world and human nature. With these three common features and the constructivist DDs in mind, we could contextualize into the learning landscape of Uniurb the overall question of how to foster SCL and student participation in university governance by reformulating it in the form of a main research question (Can an integrated approach between DT and humanities be embedded into the EHEA-guided Uniurb educational principles and practices so as to enhance SCL and, contextually, student participation in university governance?) and a subordinate one (Do students perceive themselves as full partners in HE governance as advocated by EHEA university and research ministers in all their recent Communiqués, or do they perceive themselves as consumers, i.e. as customers of university services as advocated by the economic agenda of 
the European Commission?). At this point, we could design the workshop itself. As a format, we chose the well-known d.school/IDEO ED five-stage model. For each stage, we selected DT activities and tools that might underpin the interdisciplinary heuristic framework of our project. We assumed that students' responses to the workshop activities would be affected by their own perception of $\mathrm{HE}$ and of their role as students within it. During the workshop event, we observed students' behaviors. We then analyzed the data taken from the workshop with the qualitative methods provided by the hermeneutical notion of understanding through contextualizing (s. Dilthey's comprehending) which the humanities (philology) share with DT. Quantitative methods were used to validate some of the results of our hermeneutical assessment of data and to be able to use the findings of the present workshop as a control group for further research. The outcomes of the workshop as well as students' feedback (taken right after the event and once again after one year) show that the joint approach we developed can effectively reinforce students' capacity to reflect on the stakes of present-day HE, foster their confidence in their ability to change things for the better and, especially, ignite their motivation to stand up for what they believe in. While we are designing the prosecution of the project at Uniurb, other Uniurb students have joined our vision and are engaging in this interdisciplinary enterprise.

\section{The case study}

\subsection{Setting the context: Uniurb in the European Higher Education Area}

Within the European Higher Education Area (EHEA), degree programs respond to a common set of quality assurance standards that underlie two main pillars of the Bologna process. The first pillar, SCL, was introduced into European HE policies in accordance with the aims of the Bologna process that have lead to the EHEA: the aims of closing the gap between university education and the European job market, as well as promoting Europe to a more knowledge-based, democratic, and cohesive society whose members, already in their younger age, cooperate as self-confident and enterprising citizens (the former aim predominating over the latter, s. Klemenčič, 2012; Suárez \& Suárez, 2005, pp. 29-36; ESU, 2015. S. also ESG, 2015, p. 4; QF-EHEA, 2005, pp. 161-162). SCL is one main standard for quality assurance of study programs within the EHEA (ESG, 2015, Standard 1.3, pp. 9-10). It is prescribed as a guiding principle for organizing learning programs because it "encourages students to take an active role in creating the learning process" (ibidem). This constructionist, context-related learning and teaching approach encourages students to co-build the learning process so as to co-create knowledge in a way closely linked to the learning environment and the problems at stake in a given situation; it also fosters students' self-confidence and respect for the other participants in the learning enterprise (ESU, 2015). SCL is achieved in study programs through the learning outcomes set by the so-called Dublin descriptors (DD) as prescribed in QF-EHEA (2005) and revised in the EHEA 2018 Paris Communiqué (Appendix III. S. also Jansen \& Goedhart, 2010; Klemenčič, 2017; Zara \& Stefani, 2017). The single competences and skills assessed through the DDs will be discussed in later Sections. As concerns the second main pillar, that of student participation in HE governance, a desideratum arises about what competencies exactly should be achieved by students so that they can face this complex task, and where exactly these competencies can be acquired and practiced by students in the course of their study curriculum. Both European Standards and Guidelines for Quality Assurance in the European Higher Education Area (ESG, 2015) and ECTS Users' Guide (2015), as well as many Communiqués by the EHEA ministers for research and HE, while not clearly addressing this desideratum, seem to imply that the very constructivist approach behind SCL, and consequently the very multi-, inter-, and cross-disciplinary competencies and skills acquired by students through observance of the DDs in the courses, are supposed to prepare and motivate them to successfully participate as innovators and decisionmakers in HE governance policies at their universities. Evidence from Uniurb seems to question such an assumption. A 2017 report by the governmental Agency for Research and University Quality Assurance (Rapporto ANVUR, 23/2017) has shown (pp. 6-7) that Uniurb students, despite being assisted with great care by teachers, technical staff and administrators in pursuing their curricular pathways, are not adequately encouraged to participate in strategic management, so that very few students are willing to nominate themselves as student representatives in university taskforces and offices. Interestingly, these findings correlate with an EHEA-wide decrease in student participation in the formal decision-making bodies in the last years (ESU, 2018, pp. 17-26) and EHEA students' complaintsabout the inadequate offering of proper training programs for their representatives (ESU, 2015, p. 21). Governance theory and education philosophy might help to better frame this 'wicked problem'. Klemenčič 
(2012, p. 634) distinguishes within the domain of student democratic participation in HEa 'formal' area of governing and management (through the advisory and 'political' functions of their representatives in all institutional bodies), and an 'informal' area of quality assurance (for instance, through evaluating questionnaires), SCL and other forms of involvement. As Klemenčič (2012, pp. 636650) and Sin (2015) argue, since the integration of the European Commission into the Bologna process in 2001 on the wave of the European Union (EU) modernization agenda for a knowledge-based competitive economy, management practices (such as granting autonomy while demanding accountability) have been incorporated into HE public institutions in order to make them more effective, efficient and responsive to the socio-economic demands, and to let them act more as corporate institutions. This managerial turn in HE implies changing conceptions of the role of HE from a public good with multiple individual and social aims to a service provision for industry; the role of students from decision-making partners to customers; the role of academics from educators in the broadest sense to content-transmitters for the sake of students' employability; and the role of university governance from a collegiate endeavor to a corporate strategy. On the level of student democratic participation to HE, the managerial turn has weakened the 'formal' area while strengthening the 'informal' area of participation (Klemenčič, 2012). Such EU-driven development seems to relativize the latest EHEA University and Research Ministers' Communiqués' call for students' decisionmaking power and equal partners' dignity in HE governance. Responses to the managerial turn in HE have been different in EHEA countries depending on their pedagogical and institutional traditions. Countries with a humboldtian, neo-humanistic or historicist pedagogical heritage, such as Germany and Italy, have had deeper concern with such a mindset change than those with academic traditions already service-oriented such as the UK or social corporatist Scandinavia (Klemenčič, 2012; Harmsen, 2015, pp. 792-793; Suárez \& Suárez, 2005). This concern might be a reflex, in institutional policy-makers (who are themselves mostly academics), of that distinction, long felt as a dichotomy, between natural and human disciplines or 'sciences' (Naturwissenschaften versus Geisteswissenschaften), and of that between utilitarian versus non-utilitarian mindsets, that have dominated continental European (and Italian) academic discourse in the last centuries. This mental dichotomy might make it difficult to effectively tackle this complex, intrinsically interdisciplinary problem (Buchanan, 1992; Frodeman \& Mitcham, 2007).
As Uniurb strongly commits itself to EHEA (Statuto dell'Università degli Studi di Urbino Carlo Bo, 2018, p. 2), it has undertaken a large-scale reflection in institutional bodies to foster student participation, and the workshop presented here is meant as a first scholarly contribution to this discourse. The present case-study intends to provide evidence that DT, thanks to its human-centered core, can provide - especially when sustained by some tenets of humanities epistemology - a dialogical space (in the sense illustrated in Culén \& Gasparini, 2019) where the EU's and EHEA's colliding visions of the role of students in HE governance can be reconciled, so that DT can be applied to foster students' participation both in formal and informal areas of HE governance. As an example of the latter area, DT has been embedded in SCL (which is considered in the present study more a process of acquiring and training some of the intellectual instruments and practical skills to act in governance, rather than a governance act itself); as an example of the former area, DT has been tested in view of its potential to provide some topical competencies required for student representatives along the steps of institutional decisionmaking (which are, according to Klemenčič, 2012, p. 636, agenda setting, drafting, decision-taking, implementation and monitoring of institutional decisions).

\subsection{Setting the framework: an integrated approach between DT and humanities for bachelor students}

In the academic year 2017/18, we decided to organize a workshop where we might work on these issues with a group of bachelor students. The workshop took place in Spring 2018 within the Uniurb-based author's Germanic Philology bachelor seminar. This seminar was organized according to the SCL outcomes of the DDs mentioned above. According to Jansen \& Goedhart (2010), all five DDs provide competencies that are interdisciplinary in nature, while others (CUN, 2017, p. 12; Zara \& Stefani, 2017, pp. 62-36) consider only DD1-2 (Acquiring knowledge and understanding; Applying knowledge and understanding) as discipline-specific, while seeing DD3-5 (Making informed judgements and choices; Communicating knowledge and understanding; Capacities to continue learning) as transversal (ie., multi-, inter-, cross- and transdisciplinary). The present study adopts Jansen \& Goedhart's view, as it presupposes that the competencies fostered through the DDs are a coherent system of mutually conditioning cognitive operations. Given the strict time constraints of the philology seminar 
(48 lesson units of 45 minutes each, for an overview on the Old English, Old High German, Old Norse, and other related medieval languages and cultures, each considered within the threefold philological framework of historical linguistics, textual hermeneutics, and manuscript studies including textual criticism), the challenge was to find a time-effective formatting principle for an 8-hour-workshop of which the didactic aim was to offer a 'place' inside the seminar where the students might become aware that the learning outcomes they acquire in terms of DD1-5 by learning philology can enable them, especially when sustained by a creative innovation and problem-solving approach, to participate in formal and informal areas of university governance. Since DT, in its version as a 'toolkit for innovation and problem-solving', has proven to be easily acquired by learners, at least in its basic, more intuitive and self-confidence fostering features (Rauth, Köppen, Jobst, \& Meinel, 2010), it was chosen as a formatting principle for the workshop. In order to integrate DT into the philological imprint of the seminar and the constructivist SCL principles of its didactic strategy, an interdisciplinary heuristic framework combining DT with some main epistemological tenets of the humanities had to be developed to organize the workshop. The following Sections describe the approach to interdisciplinarity chosen to develop the framework. They also report the steps of the framework creation process, as well as the methods used to develop the workshop and pursue the research question(s) through it.

\section{Interdisciplinary research as a creative design process}

As a theoretical background for developing the interdisciplinary framework on which to build the workshop, we chose Szostak (2003, 2017), as it offers a non-inductive definition of the nature of disciplinarity and interdisciplinarity, and it acknowledges the intrinsic bond between the interdisciplinary research process and creativity. According to Szostak (2003, p. 29), a community of scholars of a discipline shares: a) a set of phenomena to be studied; b) a set of (evolving) theories, often combined in an overarching paradigm; c) a method or a set of preferred methods; $d$ ) a worldview; e) 'rules of the game'. If disciplinarity results from these characteristics (especially of the first three) so as to be definable as "the application of a subset of theories and methods to a constrained set of phenomena of interest" (against the horizon of a certain worldview), then inter-disciplinarity as a principle should, reversely, be defined as "[o]penness to the application of all theories and all methods to any set of phenomena"; and, furthermore, as openness to the applications of any type of worldview (reference to Szostak's, 2003, p. 29 'rules of the game', i.e. to disciplinary standards to judge research quality, is left out from the present study). It follows that "a piece of teaching or research qualifies as interdisciplinary only if it involves utilizing theories and/ or methods and/or studying phenomena which are the province of more than one discipline (at the time it was produced)"; it should also involve worldviews and rules of the game (all citations here from Szostak, 2003, pp. 30-34, cursive by him). To the aims of the present study, a further criterion was added (from Pollock, 2016, p. 16): that of an academic home, here reinterpreted as point $\mathrm{f}$ ): an 'academic, educational or professional setting' of a discipline.

Most important for the present case-study is Szostak's understanding of interdisciplinary research as a creative design process: while integrating insights, interdisciplinarians "creat $[e]$ common ground" (2017, p. 18, Szostak's cursive). Interdisciplinary research follows conscious and subconscious thought processes along several creation steps: "asking a suitable research question, gathering insights from relevant disciplines and evaluating these, mapping interdisciplinary linkages, creating common ground among these insights, integrating disciplinary insights, developing a more comprehensive insight, and then testing, reflecting and communicating (Szostak, 2017, pp. 18-19). This case-study reflects Szostak's steps and strategies, which structure the contents of the present paper, especially as they have inspired the creation process. However, since Szostak (2017, p. 18) defines creativity "in terms of novelty and utility" and interdisciplinary creativity "as a novel and useful solution to a question or problem, which generally involves drawing connections among previously disparate ideas”, the present case-study revisits Szostak's approach on account of non-utilitarian discourses on creativity in the humanities.

\subsection{First step: assessing the disciplinary status of DT and philology}

Let us now assess the epistemological status of DT and philology as 'disciplines' in their present state, on the basis of points a-f) presented in 2.2. The assessment addresses philology in its features common to all humanities. The assessment also takes into account that scholarly organization of knowledge in Italian 
HE institutions de facto still reflects the epistemic siloing between 'the sciences' on one side, and 'the humanities and the arts' on the other, often with no clear institutional boundaries between the latter two. Points a-f) for DT have already been assessed in recent studies (this survey takes into account several literature resources regarding, among other themes, the history and epistemology of DT, design-centric culture, inter- and multidisciplinary practices, problem definition, wicked problems, innovation, creativity, STEAM: Almendra \& Christiaans, 2013; Barsalou, 2017; Brown, 2008, 2009; Buchanan, 1992; Coyne \& Snodgrass,1991; Cross, 2001; Kelley \& Kelley, 2013; Lindgaard \& Wesselius, 2017; Camacho, 2018; Diethelm, 2016, 2017; Dorst, 2011; Gasparini \& Culén, 2017; Goldschmidt, 2017; JohanssonSköldberg, Woodilla, \& Çetinkaya, 2013; Kimbell, 2011, 2012; Kolko, 2015; Liedtka, 2015; New \& Kimbell, 2013; Owen, 2007; Norman, 2013, pp. 217-257; Poulsen \& Thøgersen, 2011; Razzouk \& Shute, 2012; Verganti, 2016). In particular, Johansson-Sköldberg et al. (2013) envisage five scholarly discourses within the design area, and three discourses within the management area, with few explicit links between the two. Accordingly, they distinguish within the 'DT'-macro-area two fields of, respectively, design-related 'designerly thinking', and management-related 'DT', the first being provided with a robust theoretical body, and the second resulting from "a translation of designerly thinking into a popularized, management version." (Johansson-Sköldberg, Woodilla, \& Çetinkaya, 2013, p. 131). In both fields, the discourse on DT deals both with its close bond with design and its difference from this. As emerges from scholarship, what underpins DT is a fundamental perspective on how designers think. In their work of making, designers approach the formulation of the "problem space" and the "solution space" as an iterative process of "analysis, synthesis, and evaluation" (Dorst, 2006). This process is not sequential: designers' thinking, i.e. the way designers reflect on and upon their own work (Schön, 1983), is also the backbone of DT, as it fuels the creation of new realities in the "solution space". The difference between design and DT, as we understand it, consists in the latter being a more open plethora of different perspectives brought into the process by its different participants, which makes DT a shared mindset of reflective co-creation.

This aspect points at DT's relevance for potentially any aspect of human life, for instance, learning sciences. After 2010, a further scholarly discourse has gained terrain: that of 'educational DT', i.e. scholarly metareflection on DT as a learning approach in pedagogical, educational and learning settings of any type. This third field is still in a pioneering state, combining insights from the designerly and managerial areas of DT with learning and education theory (e.g. Braun, Moreland, Sanders, \& Gill, 2014; Burdick \& Willis, 2011; Culén \& Gasparini, 2019; Dym, Agogino, Eris, Frey, \& Leifer, 2005; Henriksen, 2017; Henriksen, Richardson, \& Mehta, 2017; Koh, Chai, Wong, \& Hong, 2015; Kurokava, 2013; Lor, 2017; Noweski, Scheer, Büttner, von Thienen, Erdmann, \& Meinel, 2012; Rauth, I., Köppen, E., Jobst, B., \& Meinel, C., 2010; Tschimmel, L., Santos, J., Loyens, D., Jacinto, A., Monteiro, R. \& Valença, M., 2015; Tschimmel \& Santos, 2018; Withell \& Haigh, 2013; Wrigley \& Straker, 2017). If we consider that, all heterogeneity notwithstanding, all discourses on DT share some essential aspects of complexity theory (for instance, an implicit or explicit understanding of DT as a 'process' and of many of its phenomena or objects as 'open systems'; s. Poser, 2012, pp. 291-311), and if we recall the origin of the very word design from Lat. designare, literally 'to set (draw; carve) a mark onto/into a surface' (thus transforming it), then we may propose, to the aims of the present study and on the basis of points a-f) described above, a heuristic, boundaryopen definition of DT as 'the process of conceiving, calling into being, and shaping new reality (in the form of new knowledge, meanings, visions, ideas, solutions, situations, environments, organizations, services, manufactures) pertaining to human attitudes, desires and needs, a process which involves cognitive, emotional and corporeal activity both on an individual and social level, and which occurs through iterative, context-related, problem-solving and solution-oriented behaviors, the meta-reflection on which is led in research, educational and professional settings'. This definition aims to highlight the fundamental insight that problem-solving, while being a key element, is not the ultimate goal of DT. What it is all about in DT, in the end, is the solution, which is such only insofar as it implies, from whatever point of view, an improvement of the human condition, and thus a new and 'better' reality.

On the basis of the works of both $19^{\text {th }}$-century pioneers and present-day pursuers of philology as a scientific discipline (e.g. Bremer \& Wirth, 2010; Canfora, 2008; Pollock, 2016; Schwindt, 2009; Schwindt, 2017; Wolf, 2012), let us now assess points a-f) of philology. The general principles of philology theory and practice

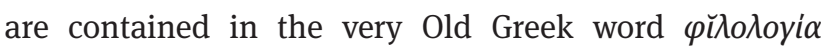

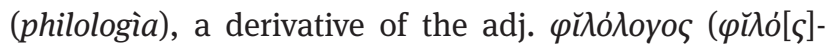

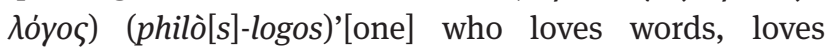
to speak; talkative' or '[one] who loves logic, to philosophically argue'; or 'fond of learning, of literature'.

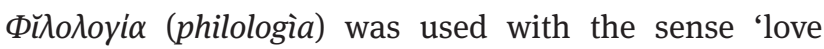
of discussion, of conversation; love of argument, of 
dialectic'; and 'love of knowledge, of learning'. Both are witnessed with these senses in authors such as Plato, Aristotle and (in the sense 'study of language and history') Plutarchus (Liddle \& Scott, 1901; Montanari, 2013). Philology as 'the act of loving words (etc.)' is thus in its very essence the dialogical process of desiring, loving, acquiring, preserving, recovering, creating and communicating knowledge (in the form of new texts, such as facsimiles or critical editions of previous ones, or other cultural outputs, such as adaptations of existing texts into translations, theater pieces, video games, movies... ). Such a dialogical process is very close to philosophy in the way this was pursued in antiquity: it is based on spoken and written words as an expression of thoughts communicated from a person to (at least) another one and vice-versa. As phenomena of philological study, words are mostly approached in written records, whose material transmission (or: 'tradition') and adaptive reception within a cultural community or across cultures is a cardinal issue of philological study. The Latin verb recordare ('to recall to one's heart', Lat. cors/cordis) originating the English word record makes it clear, like 'loving' in the Greek root of the word philology, that in philology, like in all humanities studies, a human being with his/her attitudes, desires and needs (as expressed through texts) is both the subject and the object of this science (Haeffner, 2005, pp. 19-21). The reconstruction of, and respect for, the authenticity of a text for the sake of a correct understanding of the other's point of view is the core of philological work. As a consequence, philology as a science pursues intersubjectivity (from an 'I' to a 'you' and vice-versa) with methods that are both subjective and objective (s. below its employmentofempathy).Itis thus a historicalscience (each text in its uniqueness: both an author's 'original' text and its varying testimonies) and in many respects a historicist one (since it addresses truth in its being phenomenologically experienced by historical subjects, i.e. 'relative' to them). The understanding of another's point of view as expressed in a received text presupposes, in philology, knowing (or acquiring) the cultural code and universe within which that text was originally produced and understood; on the other side, that text, especially when it is from a culture distant in time and/or place from the philologist, is, together with other texts by the same person and culture, the very 'means' a philologist disposes of while trying to reconstruct that original cultural code. This seeming contradiction, known as 'hermeneutical circle', first formulated by the philologist Friedrich Ast (1808) and Friedrich Schleiermacher (from 1805 on), presupposes an original wholeness underlying the process of interpretation, a wholeness from which both a text and its context are nurtured. For Ast, such wholeness enabling every act of understanding a text lies in 'the spirit of Antiquity as a whole' ("den Geist des gesamten Altertums", Ast, 1808, p. 179) as the quintessence of our universal humanitas. For the authors of the present case study, this wholeness lies in human subjectivity itself, since this can be conceived as 'an identity of identity and alterity' (Haeffner, 2005, pp. 19-51, esp. 46). In philology, human subjectivity is relevant also because it is the seat of $9 \alpha u \mu \dot{\alpha} \zeta \varepsilon \imath v$ (thaumàzein, Gr. 'wondering, marveling'), that is, the so-called 'philosophical marveling' about reality, arising from the innate human desire to recognize and acknowledge reality as it is in itself and for its own sake, regardless of the use one could make of it. From $9 \alpha u \mu \alpha \dot{\varepsilon} \varepsilon v$ (thaumàzein) follow both one's freedom to question virtually everything and a nonutilitarian attitude that lies at the core of two distinctions ever present in humanities studies: that between (nonutilitarian) desires and (utilitarian) needs, and between non-utilitarian and utilitarian experiences of human creativity. In the humanities and the arts, this $9 \alpha \nu \mu \dot{\alpha} \zeta \varepsilon l v-$ (thaumàzein)-inspired desire to understand another's point of view in a text (be it verbal, as in philology, or visual, as in art, or aural, as in music) has lead to research methods that are based on empathy. For philology, these methods will be shown below (Section 3.2, "Second step"). Hermeneutics as the art and science of correct, contextrelated and empathic understanding is one of the three subdisciplines shaping the theoryand practice of philology; it is philology's gnoseological backbone. The others are, respectively, the study of the language of the text(s) analyzed (now pursued with the theories and methods of historical linguistics); and the study of the texts(s) as embedded in its/their material support (with the theories and methods of manuscript studies including ecdotics or textual criticism, codicology, palaeography and, in the present days, a philological revisitation of media theory). When dealing with a philological wicked problem (such as a textual 'crux'), a philologist follows the method of recurring to these three simultaneously or in an iteration, with no fixed order as they imply each other. Since this process of understanding through contextualizing goes on potentially ad infinitum (hence the vision of an Universalphilologie among $19^{\text {th }}$-century German scholars and in present-day world philology projects such as the Berlin-based Philological Encounters), philology cannot be constrained into boundaries or endpoints - neither practically nor theoretically ("Die Theorie der Philologie ist unabschließbar“, Schwindt, 2017, p. 74). 


\subsection{Second step: combining DT with humani- ties through creative interdisciplinarity}

The task to be faced now is to filter out, where extant, some epistemological bridging points between DT and the humanities, in order to create out of them a common ground (Szostak, 2017, p. 18) on which to build for further insights. The following common points have been envisaged on the level of theory, phenomena, methods and worldviews. To start on a general level, both DT and philology are openboundaried disciplines. They are both perceivable as processes whose gnoseological backbones (respectively, abductive thinking and hermeneutics) are mutually compatible; they both address human-related, thus complex (and even 'wicked') phenomena and objects; they are both human-centered; as a consequence of their human-centeredness, both unite in themselves the gnoseological categories of object and subject (hence they mostly produce findings that are measure-resistant). They share a hermeneutical notion of understanding (philology in its core, DT in its designerly coté). Let us now narrow the scope on some of these shared features against the horizon of the specific differences, and of a topical discourse going on in human-centered epistemologies and ethics: that of the distinction between utilitarianism and non-utilitarianism.

\subsubsection{Empathy between utilitarianism and non-utilitarianism}

To start with, on the shared level of context-relatedness, the notion of empathy is relevant both in philology and in DT. In philology, talking about empathy addresses the gnoseological concept of Einfühlung, i.e. that theory of 'feeling into' Nature, human beings, and art, which was first formulated by Johann Gottfried Herder (s. Nowak, 2011). Einfühlung became the central method of investigation in philological hermeneutics (Friedrich Schleiermacher, Friedrich Ast, Friedrich August Wolf, August Boeckh; s. Wolf, 2012) and gained a main role in gnoseology and aesthetics (Friedrich Theodor Vischer, Robert Vischer, Theodor Lipps) over the whole $19^{\text {th }}$ century. Philological hermeneutics has developed Einfühlung-based methods to secure the 'authentic' utterances contained in a text. These methods draw - to put it in present-day epistemic terms on its cognitive and emotional components. The 'cognitive' method consists in reconstructing through linguistic and documentary-historical analysis the situational context within which that text was produced: the language spoken, the intellectual outputs, habits, traditions, living environments and everything that might illuminate the sense of the words as originally meant in that text. In this way, we consciously reconstruct the perspective from which the text and its meaning were produced. The 'emotional' method consists in catching the standpoint, emotions and feelings implied in that text by letting one's own arise from that (con-)textual reconstruction: feeling into those people's possible hopes, fears, etc. by trusting our own emotions arising from investigating and reading. This method has led to works such as Erich Auerbach's Mimesis (s. his remarks in the Postscript to the work). As suggested by the Greek verb $\pi \alpha \dot{\alpha} \sigma \omega$ (paskho) ('to receive an impression from', 'to be affected') at the core of the word empathy, empathy is rooted in our very bodily constitution, which makes us radically responsive to the stimuli of our living environment. We come into this world as beings 'exposed' to the Other in whatever form. Without such radical responsiveness rooted in our very DNA, we would not exist at all. From this fundamental insight, empathy is being studied by phenomenologists as an 'embodied experience' and explained within the extended mind theory as an 'extended bodily activity'. This insight also affects philology: for instance, in order to 'feel into' a medieval reader's relationship to his/her text and to written culture, having in our hands a medieval parchment copy of that text helps us much more than buying a critical printed edition in a bookshop. When we really want to sense what 'walking out for a journey' might have existentially meant in a medieval literary work, a good thing is, besides reading many medieval texts dealing with walking and travelling, to go and walk on that very track (if still extant) no matter how long it takes, applying one's imagination and emotions on the text while walking without any internet connection, recalling the words and senses as presented there, and compare them with our own. As crazy as it might sound, this is philology. Cognitive and emotional reconstruction of another individual's and community's world in order to capture the 'voice' spoken in one text is the quintessence of philological practice, as revealed already in the $14^{\text {th }}$ century in Francesco Petrarca's De remediis utriusque fortunae. An element not to be overlooked here is that 'feeling into' does not mean 'identifying oneself with'. The very effort of reconstructing, both through documentary research of the context and through nachfühlen ('feel after', s. Dilthey, 1900), makes you (painfully) aware that the other is 'other', is non-you, and prevents you from the danger of overinterpreting, that is, of projecting your own expectations and prejudices onto the other (s. also Brauer, 2013). The painful discovery that there is an 'abyss' between myself and the other, which empathy only enables me to partially 
bridge (Bracco, 2005), is in philology a precondition for objectiveness and truth, as well as a precondition for respecting the dignity of both the 'other culture' and one's own. Such respect enhances a cross-cultural mindset that inspires the program of world philology. EmpathyisalsoakeyelementofDT, bothinitsoverallhumancenteredness and in single phases of its practice. It shares significant traits with philology: empathy plays a role both on its cognitive and its emotional level (Gasparini, 2014, 2015); it underlies DT's hermeneutical potential to create new meaning and knowledge (Köppen \& Meinel, 2015); it addresses DT's cross-cultural vocation (Callahan, 2018). These analogies stated, there is also a specific difference. Much of DT scholarship assessed for the present study seems to equate 'empathy' with 'taking care of other persons'. For philology, empathy is no ethical entity: it is just the innate faculty and disposition to 'feel into' the other's inner world while maintaining a sense of one's own identity. As a case-study (Meffert, Gazzola, den Boer, Bartels, \& Keysers, 2013) in neurosciences has shown, psychopaths do not lack empathy: their spontaneous vicarious reactions are impaired, but the gap with the 'healthy' control-group is significantly reduced when they are explicitly instructed to deliberately try to perceive the others' emotions. It is one's environment and upbringing background that leads one to turn empathic disposition into action. In this, philology accords with ethics' view of empathy as a mere precondition for moral performance (Vetlesen, 1994, pp. 153-218). What I do out of my empathy, depends on my worldview: if I want to deceive and manipulate a person, there is nothing better than perceiving his/her needs and giving him/her precisely what they want in that moment, selling myself as a helper. This is very different from giving a person what they need out of real care for them, regardless of any advantage or disadvantage for me. The ethical choice depends on my worldview, on whether I consider humanity as an instrument to be used, or as an end in itself. This nonutilitarian view of empathy in philological hermeneutics explains philology's commitment against the ideological manipulation of sources and power abuse (Canfora, 2008; Pollock, 2016).

\subsubsection{Creativity between utilitarianism and non-utilitarianism}

Experiencing emotions, feelings and imagination in DT and philology, and turning them into research and practical methods, is diagnostic of the relevance of visual thinking in both fields. Symptoms are for instance recurring to perspective-taking, narration and metaphor. This leads to a further common trait: creativity. Both DT and philology (humanities, arts) recur to it on different levels of their theory and practice. Here only features that are relevant for the issues of this case-study are outlined. Discourses on creativity both in DT and humanities seem to turn around an epistemological discourse on the worldview-based distinction between utilitarian and non-utilitarian approaches. In our analysis of DT and humanities scholarship, we have classified insights according to a basic distinction between a view of creativity as 'the faculty of bringing into existence something which is novel, surprising, and appropriate (or useful)' (s. Sternberg \& Lubart, 1999), and 'the faculty of bringing into existence something which is novel, surprising, and worthwhile (or important)' (s. Boden, 2004; the social and individual dimensions of creativity as outlined in Boden, 2004, and the well-known sequence of 'convergent' and 'divergent' stages in creative thinking fit in both views). Humanities and some branches of psychology bring to light the fundamental point that something created can be worthwhile without being useful. For instance, psychology scholarship has shown that, in the case of a ca. 18-monthold child performing his/her first scribbles, these are very relevant and worthwhile to their development, since in recognizing those signs as their own, they become aware of their own self: they become aware that they are. The sense of surprise and thrill bound with this experience is precisely that innate $9 \alpha \nu \mu \dot{\alpha} \zeta \varepsilon l v$ (thaumàzein) of ours, that original marveling at the basis of every sense of surprise, which accounts for the existential component of creativity as advocated by humanities and the arts. Toddlers do not scribble out of a conscious plan to achieve something, but out of an impulse. They just 'do it'. The experience of joy intrinsic in this experience is different from pleasure achieved through satisfying a need. For this reason, surprise in non-utilitarian creation and in philosophical marveling are that one-and-the-same phenomenon which entitles us to question virtually everything and to create something just out of joy, pour la beauté du geste. The history of philology, humanities and arts is all committed to making human beings aware of their freedom and right to raise questions, to doubt, to trust one's own quests, without having to justify them: they make up our very being. In this context, the difference, ever-present in the history of humanities and philology, between non-utilitarian 'desires' and 'needs' is condensed, for instance, in Recalcati's (e.g. 2018) thought (s. also Nussbaum's, 2001, 'contemplative creation'; and Nussbaum, 2011, p. 18). This difference is also reflected in learning theory's critiques against Maslow's well-known 
pyramid of needs as a model for explaining human motivation: "[t]he hierarchy is rather doubtful and it is easy to find examples of people letting their lives, practice and preferences be directed by higher needs, although their basic needs were not covered.” (Illeris, 2018, p. 88). In DT, the usefulness-view of creativity predominates over the other without excluding it. While many studies imply usefulness and Mavlov's model, others integrate humanities' and arts' points. For instance, questioning attitude, personal courage and sustained curiosity in terms of "a capacity for childlike wonder" are some of Owen's essential criteria (2007, pp. 22-23; s. also Norman, 2016, p. 226). Verganti (2016) advocates for desire instead of needs as the guiding principle for DT. Many voices in DT point at the importance of raising radical questions and crazy 'what ifs' and 'why nots' if disruptive - not just incremental - innovation is to be achieved (s. scholarship survey in Jacob, 2018). It follows that the precondition for creating the most useful innovation is a non-utilitarian attitude to creation. This is no paradox, because there is no dichotomy between the two: they co-exist in human nature and should therefore be both acknowledged in human existence.

\subsubsection{An overarching discourse on utilitarian/non- utilitarian mindsets and its relation to human nature}

All this leads to the core question: what is 'human' in philology's and DT's human-centeredness? This question has been investigated here in terms of worldview, i.e. of the discourses around utilitarianism and non-utilitarianism presently going on in DT, the humanities and EHEA educational agenda. We adopt the phenomenologist thesis that human 'essence' cannot be defined but only experienced in fieri (s. Haeffner, 2005, p. 14). Since we can neither define (Lat. definire 'to set boundaries') nor comprehend (Lat. comprehendere 'to catch in one's grasp') human essence, we cannot possess it, which guarantees for our freedom and for the validity of Kant's imperative to treat humanity never simply as a means but always at the same time as an end in itself. Human freedom as well as $9 \alpha \nu \mu \dot{\alpha} \zeta \varepsilon l v$ (thaumàzein) as its main expression are at the basis of humanities' and arts' demands that societal agendas should not be determined by utilitarianism as their ultimate principle. As for DT, a trend can be recognized towards a shift to a discourse where 'humancenteredness' no longer means merely 'customercenteredness' and a human being is not reduced to his or her being a potential 'user'. Accordingly, the 'material DT toolkit' itself has grown more and more into a reservoir of devices taken from the arts, such as theatre warming-up and trust-building techniques, or creative writing (the love and break-up letters employed in the workshop of the present case-study, for instance). This, too, testifies to DT's interdisciplinary potential and to its openness to educational domains where it can help create, improve, or innovate situations and human interactions per se not directly, or not exclusively, determined by material needs.

\subsection{Third step: embedding the common epistemological core into the constructivist SCL-based DDs of the philology seminar}

The main question of this case-study, how to foster SCL and student participation in university governance through DT, can be reformulated now as 'why do students not participate enough in HE governance?', 'how to solve this problem?' and 'can an integrated approach between DT and humanities be embedded into the EHEA-guided Uniurb educational principles and practices so as to enhance SCL and, contextually, student participation in university governance?'. The question why students do not participate enough in HE governance should be addressed by taking account of the conflict, already outlined in the previous Sections of this study, between a vision of students as full partners in HE governance as advocated by EHEA university and research ministers in all their recent Communiqués, and a vision of students as customers of university services as advocated by the economic agenda of the European Commission. In the first case, students are expected to behave as active decision-takers, as trained through the DDs, and invest time and energy for the common good, as requested for democratic citizenship; in the second case, students are expected to behave as 'individualistic' customers (i.e. consumers): using a requested product and influencing the 'university market offer' by rating its quality. How do Uniurb students perceive themselves and behave? Do their self-perceptions, motivations, and attitudes suggest that EHEA students have gradually internalized the corporate mentality of the modernization agenda? Are there any differences, in this respect, between humanities and non-humanities students? These questions (except the last one, to be pursued in a future workhop, s. section on Conclusions) were addressed in the workshop on the basis of the following interdisciplinary heuristic framework. Keeping in mind Wittgestein's notion of 'family resemblance' (Familienähnklichkeit), we can frame the link between DT and philology (humanities, arts) within the EHEA 
educational principles of SCL as expressed in the DDs: the latter are a constructionist, context-related approach which shares some of its essentials with DT, some others with philology, and some others with both; on the other side, philology and DT share a common epistemic core (s. previous sections) with each other, and single aspects with the DDs. All epistemic links in the family resemblance of DT, philology, and SCL are grounded on the fundamental insight that, when focusing on students, 'we, the humans' with our desires and needs are both the investigating subjects and the investigated objects of this study: this overcomes precisely that split between nature and culture, between 'I' and 'you', between 'the arts' and 'the exact sciences', which from the late $19^{\text {th }}$-century on had been parceling knowledge into a myriad of disciplinary silos, the 'exact' ones with their object-based standards of scientificity (i.e. measurability, reproducibility, etc.) imposing themselves on the others (Peels, 2018). Dewey's (1929) call for 'science as art', based on a union of theory and practice, has helped overcome this split and opened up the way to present-day interdisciplinarity. Dewey's pragmatic and constructivist notion of knowledge behind SCL and the DDs may support the role of DT and humanities in creating dialogical spaces for tackling the complex challenges of our era including that of HE governance, as disciplines "both for science and for life" (Pollock, 2016, p. 13). So a common ground is given now for an interdisciplinary creative approach that aims to provide students with the competencies and skills required to participate in the steps of a HE decision-taking agenda outlined by Klemenčič (2012, p. 636). This common ground links DT, humanities and the DDs into a heuristic framework for the workshop through the bridging points outlined above: (cross-cultural) empathy, creativity, and an overarching discourse on utilitarian/non-utilitarian mindsets that ultimately springs from the issue of what it means to be human. This heuristic framework built the basis for designing the workshop.

\subsection{Fourth step: designing the workshop}

To this point, one major problem has been stated ('EHEA and Uniurb students do not participate enough in university governance') and both a main and a subordinate research question (RQ1 and 2) have been posed to solve it: RQ1: 'can an integrated approach between DT and humanities be embedded into the EHEAguided Uniurb educational principles and practices so as to enhance SCL and, contextually, student participation in university governance?'
Drawing on the interdisciplinary heuristic framework that has been created to this aim, $R Q 1$ will be tested in the workshop by choosing tools and practices that imply students' empathic, creative and humancentered attitudes and behaviors, and by observing and evaluating these (with hermeneutical methods described in the section Analysis of evidence while taking into account the worldviews underlying them); RQ2: 'do students perceive themselves as full partners in HE governance as advocated by EHEA university and research ministers in all their recent Communiqués, or do they perceive themselves more as consumers, i.e. as customers of university services as advocated by the economic agenda of the European Commission?' We expect that students' self-perception as full partners in HE governance will be revealed by a major focus, in students' responses during the workshop, on nonutilitarian issues and behaviors, including the willingness to invest time and energy for the common good. The following synopsis of the overall research design highlights the place of the workshop in it. This will help bring to light the rationale behind the single steps of the workshop in the next Sections.

\subsubsection{The overall research design: a synopsis}

The first (light blue) area represents the educational setting of the project: the philology seminar. The seminar itself (tot. 48 hours, including the 8-hour DT workshop) started in February 2018 and ended in May 2018. The area indicates which aspects of the interdisciplinary framework of this project - creativity, empathy, discourse on utilitarianism and non-utilitarianism in a hermeneutical horizon were most intensively trained on the level of the single DDs during the learning activities in the philology hours preceding and following the workshop sessions. In this way, the students came into the workshop with a receptive mindset and were able to better capture connections between DT and the humanities not only during the workshop, but also in the philology hours that took place between Session one (four hours, March 2018) and Session two (four hours, May 2018) of the workshop itself. The light yellow area in the middle represents the workshop. This was designed according to the d.school (/ IDEO ED) multiple-stage model of 1) Empathize (Discovery) - 2) Define (Interpretation) - 3) Ideate (ideation) - 4) Prototype (Experimentation) - 5) Test (Evolution). In each of these stages, we drew on our interdisciplinary framework as well as on insights from our previous experiences with DT. So we could select from the DT 


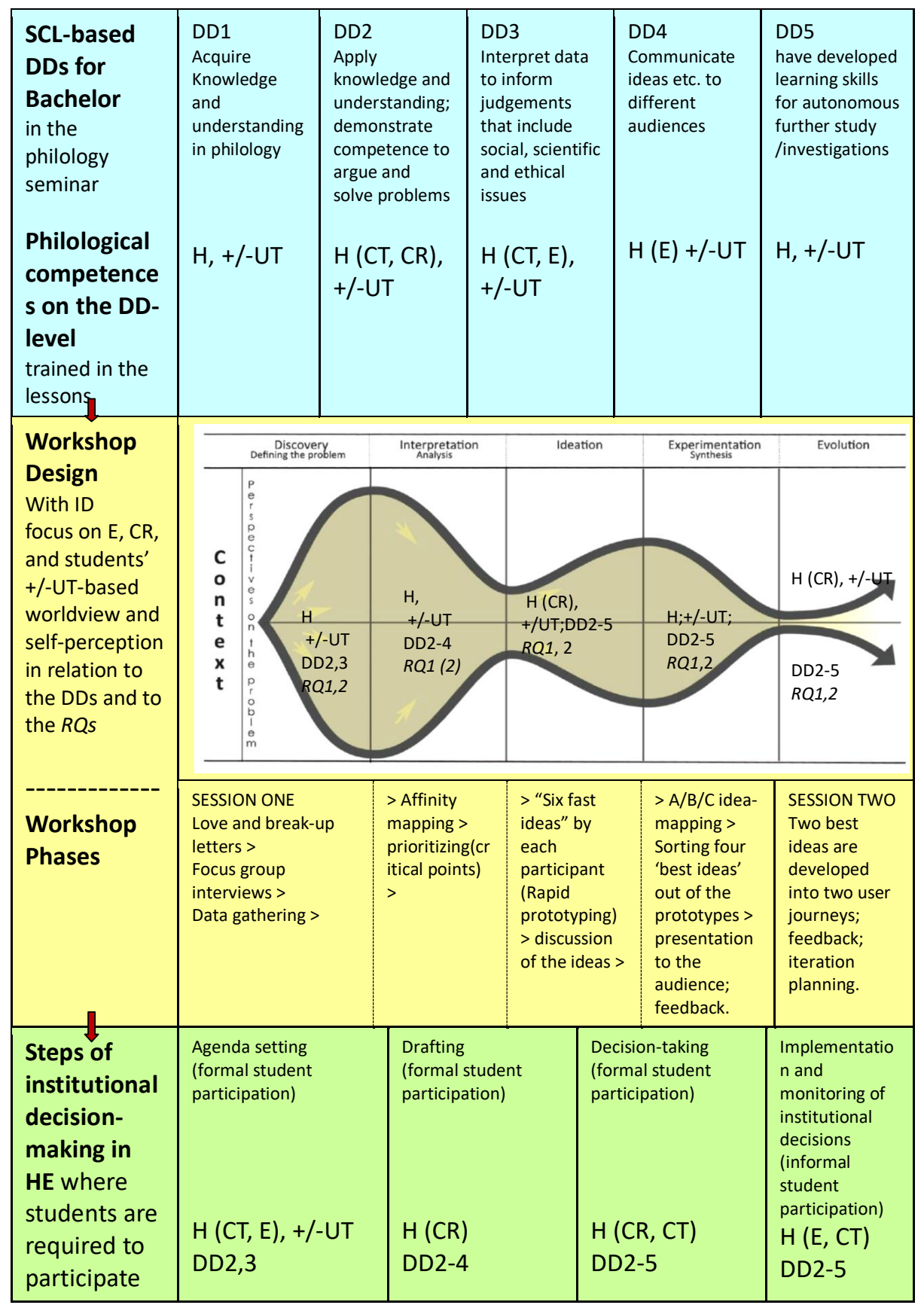

Figure 1: Synopsis of the research design. (The image of the DT process in the middle is taken from Culén \& Gasparini, 2019; abbreviations such as RQ1, RQ2 etc. have been added for the present study).

Legend:

- the DDs are given in an abbreviated form (for a full description of them as adapted to philology, see the seminar program website https:// www.uniurb.it/syllabi/253407)

- ID = interdisciplinary (it relates to the epistemological bridging points between DT and the humanities)

- $\mathrm{H}=$ Hermeneutics with its single components as practiced in philology $(\mathrm{E}=$ empathy, $\mathrm{CT}=$ contextualizing, $\mathrm{CR}=\mathrm{creativity,}+/ \mathrm{-UT}=$ assessment of utilitarian/non utilitarian worldview when applying hermeneutics on texts and/or (situational) contexts, or on themselves as individuals and students).

When only $\mathrm{H}$ is indicated, it means that hermeneutics as a whole is applied; otherwise, focus on its single components (CT, E, CR; +/-UT) is indicated.

$R Q=$ Research Question

$\mathrm{DD}=$ Dublin Descriptor. 
toolkit those activities that might activate the students' competencies in empathy, creativity, and knowledge of utilitarianism and non-utilitarian worldviews, that they already had developed and practiced in the philology hours preceding Session one of the workshop. In this way, we could observe and assess their behaviors during the workshop to pursue our research questions. The light green area represents the steps of institutional decision-making in HE as outlined in Klemenčič (2012, p. 636). For each of them, we indicate the domain of student democratic participation required by the EHEA. We also suggest which of the competencies and skills that students can develop and train through our joint DT-humanities approach might support and enhance their proactive contribution to each step of institutional decision-making, and which DDs, in our view, they match along those steps. This area could not be directly investigated during the workshop: it is being pursued in a further DT-project at Uniurb which we are designing together with some students representatives at Uniurb as well as some of the present workshop participants to prosecute the present research (s. details in the Conclusions). However, the contents of both user journeys created by the students in Session two of this workshop provide valuable evidence that the students were able to gather insights on how to behave strategically on an institutional and stake-holder level in order to make their projects real (s. below, Sections 4.2 and 5.2).

\subsubsection{Addressing students for the workshop}

The workshop was one of two optional labs included in the philology seminar program, the other one being a theater workshop. So we could be sure that only students would enroll who were really interested in the project. Many workshop participants, although not all of them, already knew each other. They were purposefully not informed on the aims of the workshop before attending, except for a guest-lecture on DT by the UiO-based co-author of the present project. Even the major focus put on hermeneutics by training students to understand through contextualizing and by working intensively with them on empathy, creativity, and (non-)utilitarian awareness in the philology hours preceding Session one of the workshops had not been explained to the students in terms of a 'preparation for the workshop'. We did this to elude the risk that the students would make assumptions on the workshop to come, or enter it with prejudicial expectations.

\section{The workshop event}

The workshop took place in two morning sessions, in Spring 2018. In Session one, fourteen students came from the philology bachelor course; eight from a philology master course and one from a humanities PhD-program. Four faculty members (including the Uniurb-based author of this study) took part in Session one.

\subsection{Session one}

Session one of the workshop took place on one March morning (9am to $1 \mathrm{pm}$ ).

Structure of Session one: 1) Love and break-up letters (divergent): each participant wrote one love letter and one break-up letter to Uniurb. The task communicated to them was simply: "Write a love letter to your university" and then the same instruction for the break-up one. We reassured them that their letters would remain anonymous so that they could feel free to write as they liked. After each writing round, their letters were attached to the room walls; at the end, we invited the participants to read them all. This task is the only one in the workshop where students worked individually from beginning to end. To us, this was important in order that we might observe their personal motivations, priorities, lifestyles and attitudes. These fields were relevant both to investigate how far individual students would spontaneously activate the skills of empathy, contextualizing, creativity as well as a (non-)utilitarian perception of themselves and of HE when describing their own actual relationship to Uniurb, and when imagining and advocating a potential 'novel' Uniurb. Furthermore, since the goal of the love and break-up letters activity is to support divergent thinking (more specifically, of "retrieving a broad range of existing knowledge", Cropley, 2006), we chose this activity in order that participants, while reading all letters, might enrich their own perception of Uniurb and of being a student through their fellow students' eyes. The data we gathered here gave us clues both for $R Q 1$ and 2 (s. Section 5.1.1).

2) Focus group interviews in four groups (divergent): in each group, one faculty member was asked by one student about their past experience as an undergraduate or postgraduate, while the others in the group were listening and taking notes. Faculty members were asked questions such as: "Right after your study, how did your university studies influence your next phase in life?" "Could you mention who influenced your decisions during your studies? How did they?" "How did you find, at that time, information about other 


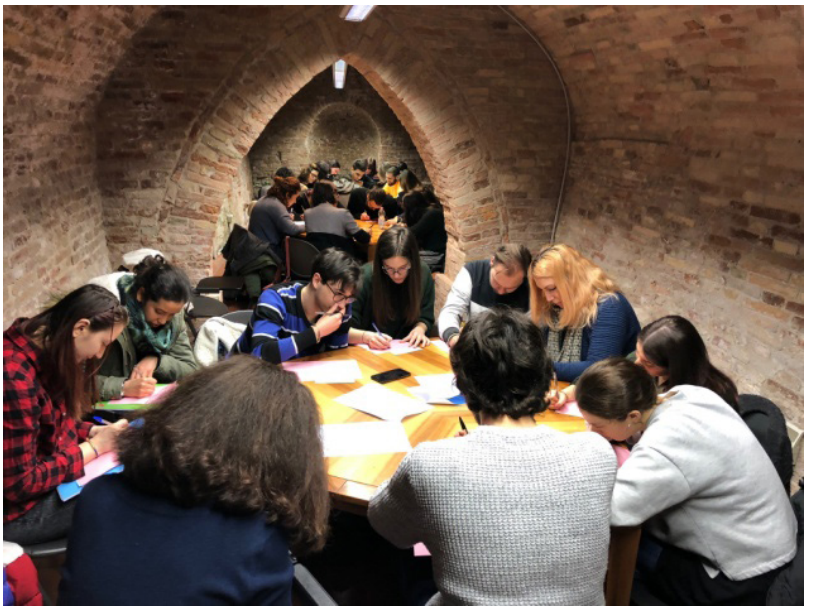

Figure 2: Session one. Participants while writing 'love letters' to Uniurb (photo by the authors).

studies in Italy or abroad?" (s. full question list in the Online depository). Besides an overall set of questions provided by us, students might ask additional ones. In this guided interview, students took on the role of design thinkers and faculty members took on the role that they had played as students and young adults, i.e. as the 'users/addressees' of the DT process; however, being interviewed in a stage of their adult life later than that addressed through the questions, their accounts could give the interviewing and listening students a wider perspective on the long-term consequences of choices to be made during university years. Thus, at the end of the interview, the Uniurb-based author of this study, for instance, was asked by 'her' group even questions with a more personal, existential tone, such as: "Is there any decision taken during university that has deeply affected your personal or professional life till now? How much of 'that' young woman has still remained alive inside you?" The aim of this exercise was to activate empathy and perspective-taking (contextualizing) on a group level, to raise shared participation in another's point of view - all competencies that had been trained on DD2-level in the philology hours preceding the workshop - and provide us data to evaluate for $R Q 1$. On the other side, this was a guided interview where students had to ask mainly pre-instructed questions. We did not plan to gather information on spontaneous students' position-taking on (non-)utilitarianism (thus we did not observe students' behavior for $R Q 2$ here).

3) Affinity mapping and prioritizing in four groups (first divergent, then convergent): we asked the students: "What challenges/possibilities do you have today at Uniurb and what needs should Uniurb cover in future to help you achieve your goals?" In each group, attendants were instructed to gather insights about this question from the remarks contained in the love and break-up letters as well as from their interview notes, and to write on post-its those insights as well as new ones that might have come to their minds while making connections. This task of developing and being creative by "associating ideas from remote fields" (Cropley, 2006) was again divergent. We chose it because it is not so time-consuming. More importantly, we wanted to create in students a 'mental space' that would grant them the freedom to non-utilitarian insights beside the utilitarian ones implied in the need-and-goal-oriented content of the task given to them. This should support in the students' minds the welcome paradox of a 'hermeneutics of creating non-utilitarian solutions' beside utilitarian ones. This activity of writing insights on post-its was done individually. The participants then attached all post-its onto a large sheet of paper (one for each group) and read them all in their group. By discussing together, they then gathered the post-its into affinity groups on the same large sheet according to main concepts (thematic clusters) that emerged from the data, and sorted out of them one or maximum two critical points representing the two most important challenges and needs for all. This concluding phase of the activity fosters convergent thinking. The critical points were established through voting (our instruction: "put one 'CP' on one or maximum 2 topics that you consider critical". The 'CPs' were then summed up). With respect of the overall research design, the aim of this phase of the workshop was to activate in the students, through the joint DT-humanities framework, the competencies and skills trained on the level of DD2,3, 4, and 5 in the philology hours preceding the workshop both individually and collectively: we expected the individual students to hermeneutically comprehend the data gathered by themselves from letters and interviews, and then, within the group, to select them in order of relevance for the students' personal, educational and professional development. We chose this design activity also to allow each participant to present his/her own point of view to the rest of her/his group, thus experiencing how true common understanding can only emerge in a space of equal rights, possibilities and dignity, where diversity is acknowledged as a gift. Furthermore, by asking students to establish priorities together through shared group discussion we aimed to foster their ability to co-create meaning (= shared hermeneutics through shared contextualizing). As for the RQs, this phase is relevant mainly (but not exclusively, as will be pointed out later) for RQ1. Since our instructions given to students for this activity pointed at their needs and (educational and professional) goals, we 
left RQ2 more in the background: the words 'needs' and 'achieve your goals' pre-guided students in a utilitarian direction. However, some data from this phase were collected that suggest participants' non-utilitarian perception of their role as students and of HE in spite of the 'utilitarian' direction of the task. The implications of this are discussed in Section 5.1.3.

4) Prototyping with 'Fast ideas' (divergent): in each group, each participant was instructed to formulate at least six ideas (proposals, possible solutions) addressing the critical point(s) of their own group in ten minutes. For instance, problems with transport services were chosen as a critical point in all four groups (independently from one another). Accordingly, within each group participants conceived ideas such as "initiate a signature action to reactivate the railway connection to Urbino", "organize a funding campaign for activating a shuttle", "find a way to manage that university fees include transport service", "obtain that commuters may take online-exams", and so on. From this activity we aimed to gain evidence that participants could apply to this DT setting the skills acquired in their philology lessons on the level of DD2-5: they were stimulated to imagine (i.e. conceive in their minds, create ideas for) solutions to their critical points through pro-actively contextualizing them in the Uniurb and Urbino territory and through empathizing with the network of stakeholders involved in each critical point. Data from this activity should be assessed for $R Q 1$ and RQ2.

5) $A / B / C$ idea sorting and 'best idea' selection (convergent) Each student was invited to present their ideas to their fellow group members so that the experience of feeling taken seriously in a place of equal rights and dignity might be deepened. In doing so, they also had the possibility to combine ideas into more advanced ones or add new ones during this process. While discussing the ideas together, they divided them, on the basis of shared insight, into subgroups: A (ready-to-start) ideas, B (midterm) ideas, and C (long-term) ideas.

After this, each group chose out of the A/B/C sorting one idea to be proposed as their 'best' one, and presented it to the students from all other groups as an idea to be concretized. We did not instruct them on what criteria should define a 'best' idea. Each group developed their own preference criteria within the overall horizon of "What challenges/possibilities do you have today at Uniurb and what needs should Uniurb cover in future to help you achieve your goals?". Three out of four groups chose A ideas, i.e. short-term ones, because - as they stated - "we would like to see them come true while still at Uniurb”. One group chose

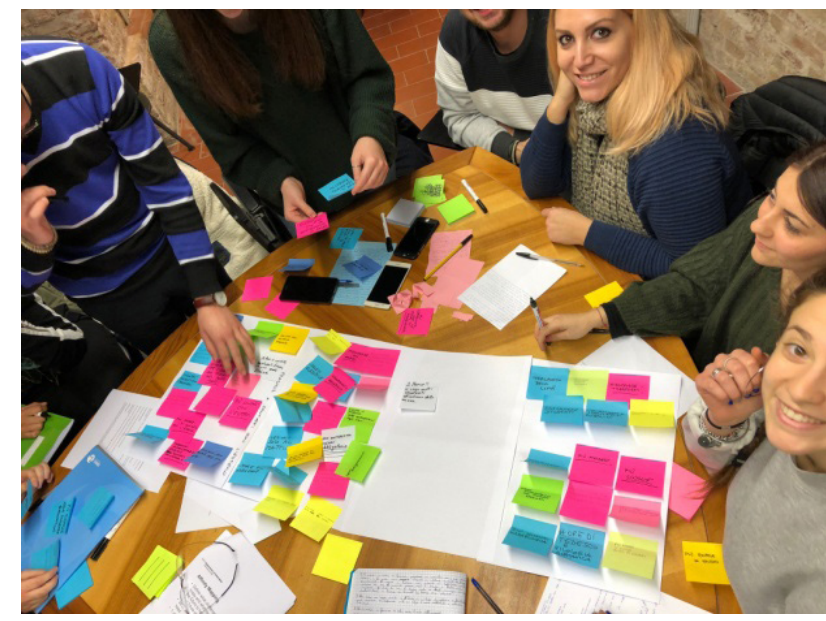

Figure 3: Affinity mapping (photo by the authors).

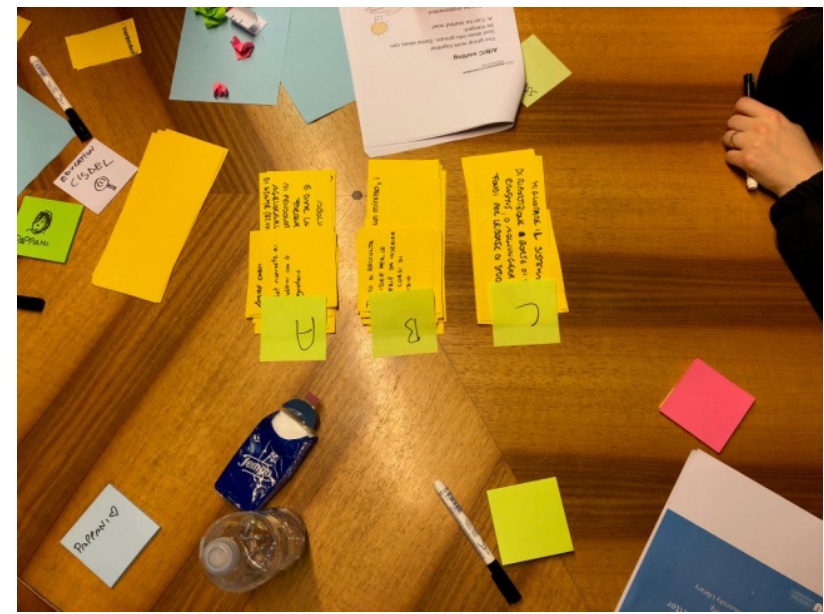

Figure 4: The A/B/C ideas of one group (photo by the authors).

a C (= long-term) idea because, as they argued, it would support all Uniurb students, even though the times required to make it real would be maybe too long for the workshop participants to enjoy it. The four 'best' ideas are described and evaluated for RQ1 and RQ2 in the Section on the Data analysis.

5) Feedback. Each group had a large sheet of paper where the students could write a line or a word about the workshop (s. Online depository for full texts). Further feedback was given once back in classroom in the following weeks that confirms that taken at the end of the workshop. Feedback is relevant for both RQs (s. below, Section 5.3) 


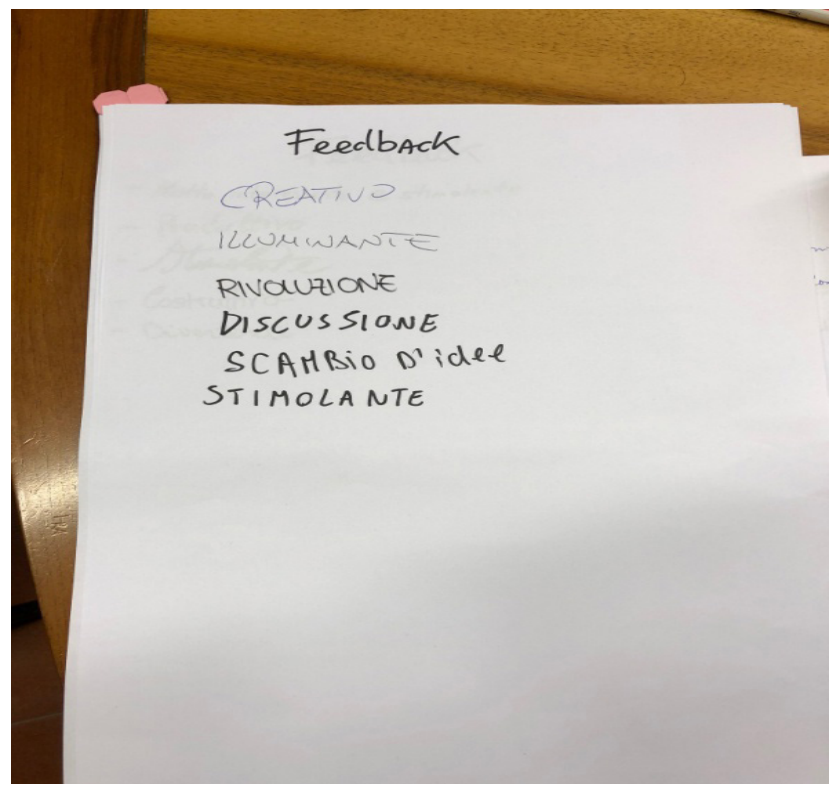

Figure 5: Feedback from one group ('Creative; enlightening; revolution; discussion; exchange of ideas; stimulating') (photo by the authors).

\subsection{Session Two}

Session Two of the workshop took place on one May morning ( 9 am to $1 \mathrm{pm}$ ). 17 students out of 23 participated (some commuters from Session one not being in Urbino right then). Faculty members were not invited. In this session, students had to develop two user journeys out of two of their 'best ideas' from the final phase of Session one. We chose this activity because of the opportunity it would provide for students to express their creative and decision-taking skills both according to our joint DT-humanities framework and its embedding in the DDs - here especially in DD5. Since a user journey implies, both on an individual and collective level, employing all the skills and competencies related to hermeneutics (understanding through contextualizing, creativity, empathy) and the capacity of distinguishing utilitarianism from non-utilitarianism in a shared problem-solving context, we expected Session two to provide us with data to be assessed both for RQ1 and 2 . Structure of Session two (user journey):

1) A brief resumé of DT and introduction to a user journey: a warming-up on the essentials of DT and on the contents of Session one took place in a dialogue in plenum. After this, students were introduced to what a user journey is and to which aims and how to create one. Students were also made aware that also during Session two, while creating 'their' user journey, they would both play the role of design thinkers and that of the end-users/ addressees (i.e. take on and hold a double point of view during the whole process).

2) Having the four 'best' ideas from the final phase of Session resumed on one sheet, the participants voted for two ideas out of them. Then they formed two groups: each of them developed one of both ideas into a user journey. These ideas addressed student apprenticeship programs (group A) and public transport (group B). (for the contents s. Section on data analysis and s. videos on the Online depository).

3) Each participant gave their feedback on Session two on a poster (s. section on Data analysis and Online depository).

\section{Data analysis and discussion of the evidence}

The types of questions posed in a study as well as the methods of data gathering and analysis adopted to answer them depend on the nature of the objects and phenomena observed. In this case, the 'phenomenon' observed are students and their behavior in a workshop designed to help solve the problem of non-sufficient student participation both at Uniurb and (few countries excepted) EHEA-wide. Students cannot be investigated as mere 'objects' of this research: they are human beings whose subjective motivations are influenced but not determined by external conditions. As argued before, in human-centered scholarship, 'we, the humans' are both the investigated objects and the investigating subjects of our research. The epistemological choice here is therefore - following Dilthey - not so much to try to explain, but rather to try to comprehend students' behaviors and decisions. Accordingly, the perspective taken is hermeneutics - a perspective shared both by philology and DT, and well-known by humanities students - with data being qualified with reference to the interdisciplinary framework described above, rather than quantified (this taking place only as far as percentages can shed further light on our issues, or as far as the data measured might be employed as a control group for future workshops). 

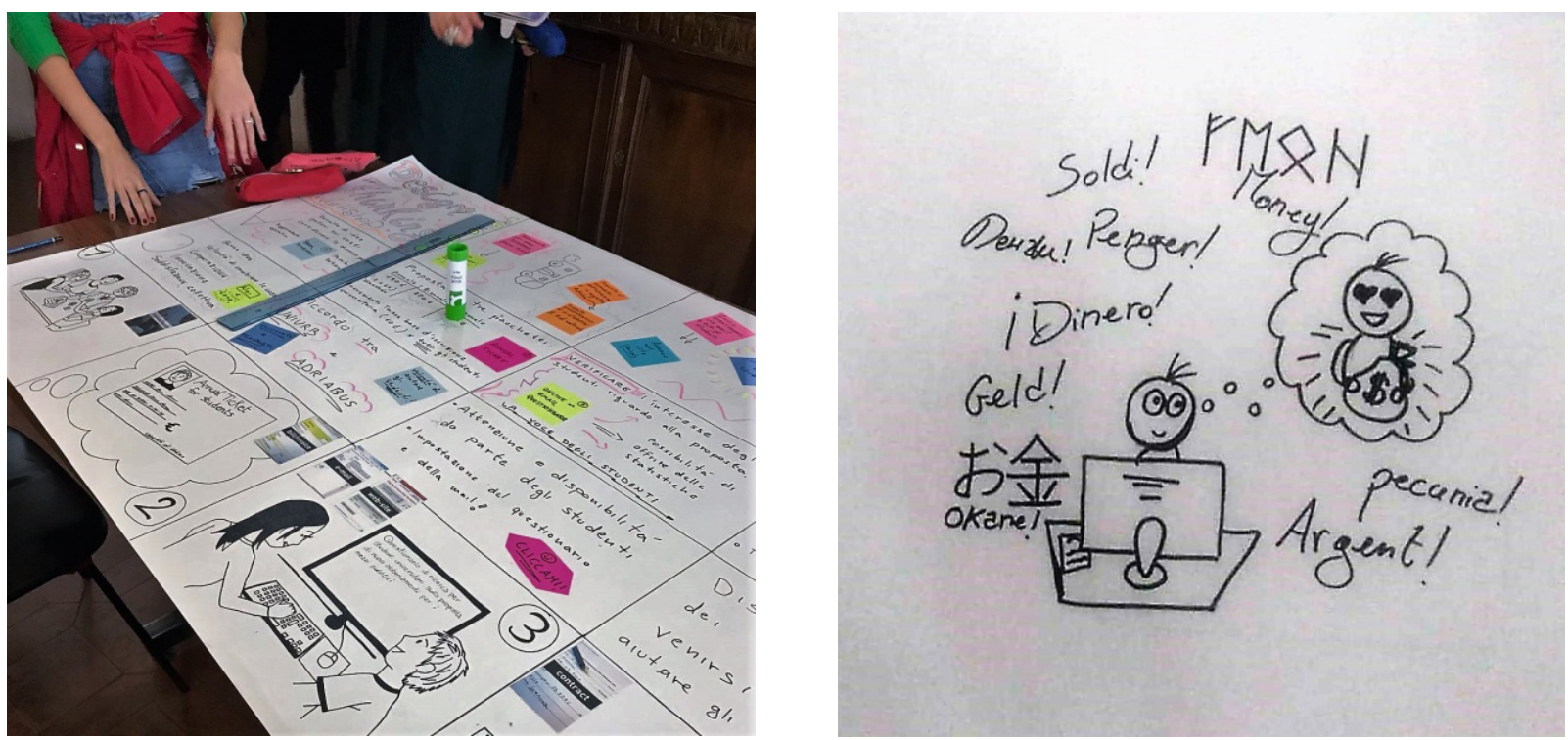

Figure 6: Session two. User journeys of group B (the initial steps) and A (a 'magic moment'). (Photos by the authors)

\subsection{Data from Session one}

\subsubsection{Data from love and break-up letters}

To begin with, we analyzed the contents of the students' love and break-up letters taken together, in order to get a first glimpse of the participants' perception of Uniurb and of how they feel being part of it. We used the simple method of searching for utterances that might unmistakably fall under the categories 'I appreciate' (= PROS), 'I do not appreciate' (= CONS) and 'I wish/desire/need/suggest' (s. materials in Online depository). For instance, a sentence like "Gazing at the beauty of your buildings and of the landscape around you feels me with joy and new strength every morning when I walk towards you [Uniurb]" was classified as a PRO of studying at Uniurb. The findings from this investigation (s. Figures 7, 8, 9) confirm some of the items from the ANVUR- and Uniurb-driven quality assessment surveys: for instance, ill-organized lesson schedules and secretariats among the CONS, and passionate and helpful teachers among the PROS. On the other side, students' spontaneous utterances in the letters reveal a datum that is not detected through the kind of guided questions posed in the official surveys: many participants did not distinguish in their letters between 'Uniurb' and the 'Urbino' town. Even though the task given was to "Write a (love/break-up) letter to Uniurb", 15 letters out of 46 started with "[Dear] Urbino", and many letters describe the structure, buildings, landscape, even the inhabitants of Urbino as an integral part of Uniurb. This strongly suggests that a significant part of the participants imagines Urbino as a whole living and learning landscape, with its PROS (for instance, easy socializing and making close friends) slightly predominating on its CONS (e.g. "nothing to do in the evening"). The same impression emerged when analyzing data from the Affinity mapping phase: just to mention one example among many, a student complained in a post-it about high transport fees "inside university", as if the Urbino urban area coincided with the university boundaries. Out of four groups, only one mapped some post-its as "Urbino" versus "Uniurb". Such evidence for a campus-town feeling will result again when assessing the data from the Prototyping phase (fast ideas) and from the Best idea phase, as there seems to be evidence that the workshop students connect their role as students with that as (proactive) citizens. This is relevant to the aims of the present study.

After this overall orientation, we zoomed in to analyze the letters according to the aims of the workshop. The data from the love and break-up letters are relevant both for $R Q 1$ and $R Q 2$ : evidence to be searched for here is individual students' spontaneous activation, in the context of the DT workshop, of those hermeneutical skills of empathy and creativity that the students had already trained in their philology lessons, and their activation of a utilitarian or non-utilitarian mindset (s. Figure 1, Synopsis of the research design). Especially the last factor might be informative for RQ2. Our method for data assessment starts from an analysis of the concept of philological hermeneutics and of utilitarianism in terms of intensional semantics. Drawing on Frege's logic, linguistics conceives the intension of a 
Pros of Uniurb (university, campus, town)
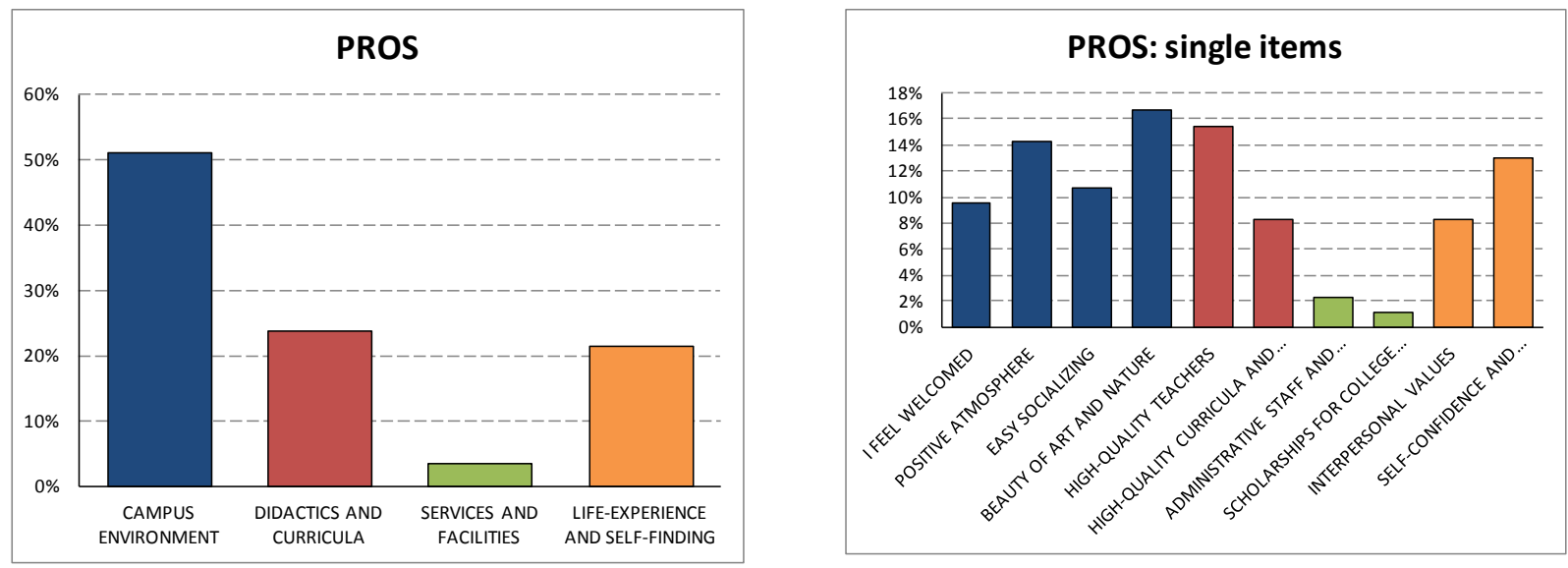

Figure 7: Tot. 84 'pros' remarks on Uniurb in the students' letters (here in percentages)

Cons of Uniurb:
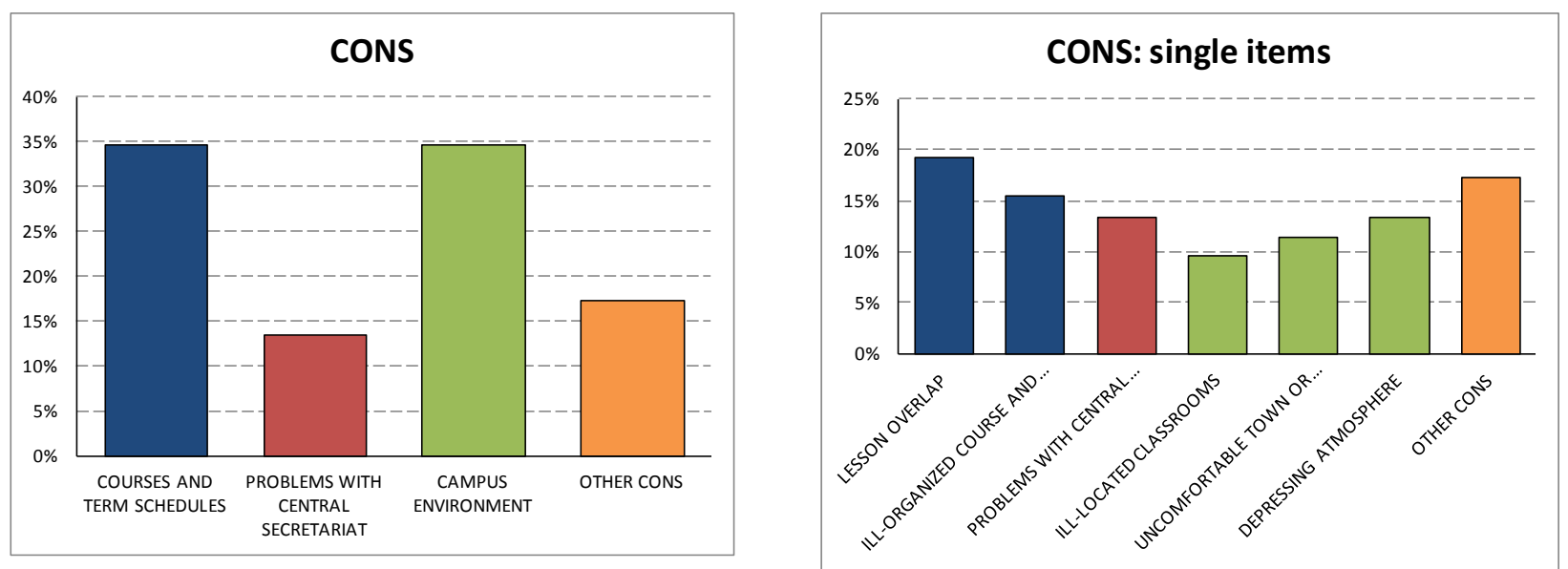

Figure 8: Tot. 52 'cons' remarks on Uniurb in the students' letters (here in percentages).

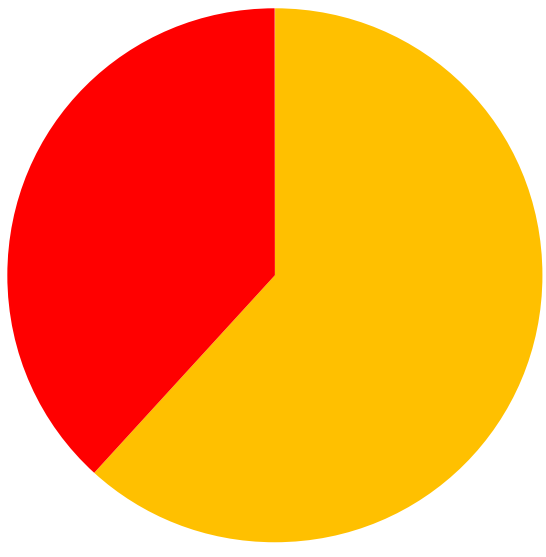

Figure 9: Pros vs. cons proportion. term as "the set of essential properties which determines the applicability of the term.” (Lyons, 1977, p. 159). Thus, we first analyzed the meanings of the terms philological hermeneutics and utilitarianism according to 'meaning (or 'sense') inclusion' (= 'intension') (s. Lipka, 2002, p. 65). Following Figure (10) resumes the essential properties of - cons the terms philological hermeneutics and utilitarianism in their common use. The layout of the 'spheres' points out that there is no semantic hierarchy between the single essential properties of both terms.

Second, welooked for 'matches' in the broader context of the love and break-up letters: we identified utterances in them that might relate to the essential properties of the intensional meaning of philological hermeneutics (esp. empathy and creativity) and of utilitarianism (esp. the understanding of creativity in it). Utterances on the text 

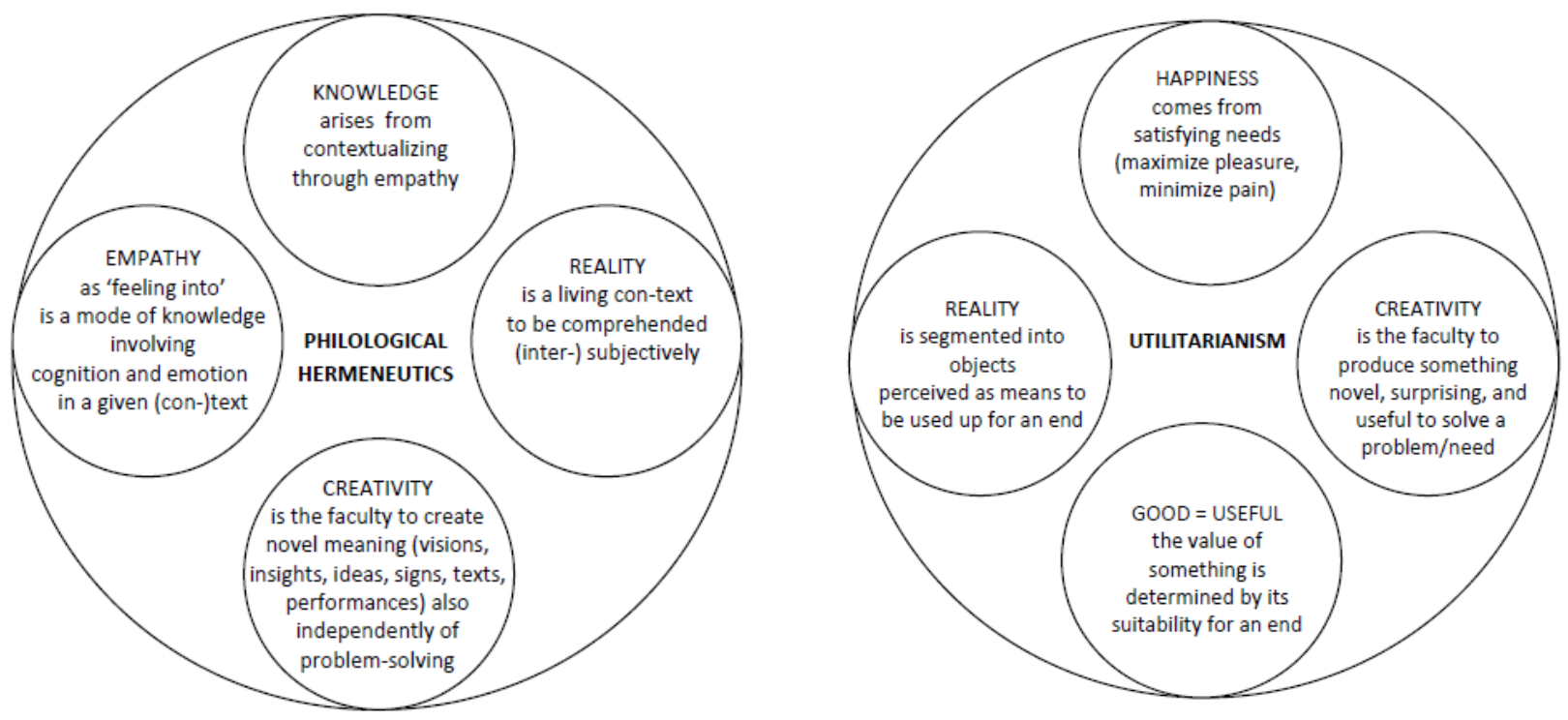

Figure 10: Intensional meaning of philological hermeneutics and utilitarianism.

surface of the students' letters that 'match' the essential features of the intensional meaning of hermeneutics and of utilitarianism are relevant for our study as they suggest a philology students' mindset that is empathic, creative, able to contextualize (since hermeneutics means understanding through contextualizing), and inspired by a (non-)utilitarian worldview. The kind of evidence we gathered here has a mere heuristic value, as hermeneutics is no exact science: any text is by its own nature polysemous and multilayered. In fact, the students' word-choice in their letters often evokes a 'bigger picture'. This is true especially for clues for (non-)utilitarianism. Let us consider, for instance, an utterance such as "[C]rescendo, non avrei mai creduto, dopo tutti i miei studi, di finire a fare ciò che amo proprio qui”. ("While growing up, I would have never believed that after all my [high-school] studies I would end up doing what I love precisely here [at Uniurb]") from the letter $1 \mathrm{~L}$ in the Online depository: on one side, Uniurb seems to be seen here as a means to an end (+UT); on the other side, this is formulated through such words (... "what I love") and in a general context (s. letters $1 \mathrm{~L}$ and $1 \mathrm{~B}-\mathrm{U}$ in the Online depository) that suggest an existential involvement of an own deep desire (-UT) far beyond a mere 'service-consuming' attitude to HE. The same is true of this letter defining future as a 'gift'. In the Online depository the complete list of love and break-up letters has been checked for utterances referring to creativity, empathy and a (non-)utilitarian worldview, i.e. the three epistemological bridging points between DT and the humanities (philology) that the students had already trained through the SCL-bases DDs in the philology lessons preceding the workshop. In the workshop itself, these bridging points were activated again in the students' minds through the task of writing the letters. Evidence for creativity results both for findings that refer to a nonutilitarian understanding of 'creating' (i.e. creating not necessarily to solve a problem or satisfy a contingent need or some other kind of use) and a utilitarian one. Figures 11 to 14 resume the assessment results.

We gathered evidence for empathy and creativity simply by rating the difference between L and B-U letters. In the case of utilitarianism or non-utilitarianism, we classified findings (whether from L or B-U letters) as 'utilitarian', 'non-utilitarian', and 'neuter (= might be either)'.

As results from the assessment, there seem to be more evidence for empathy, creativity and a non-utilitarian mindset in L letters than in B-U ones. Such a correlation between creativity, empathy and non-utilitarianism might at first sight suggest that Uniurb humanities students, when left free to express themselves, seem to be happy as their love letters imply - with a state of mind that has not yet internalized an image of a student as a consumer of their experiences with Uniurb. Interestingly, evidence for non-utilitarianism slightly predominates even when assessing L and B-U letters together. As for the B-U letters, it is significant that most of their complaints focus on some basic 'gross' disservices or discomforts such as lesson overlap, ill-organized schedules, difficult access to bureaucratic information, geographic isolation, and high living costs (s. Online depository). 


\section{Empathy in Love and Break-up Letters}

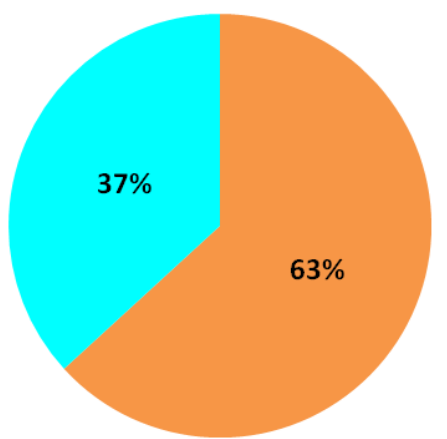

Creativity

\section{in Love and Break-up Letters}



Figure 11: Empathy and creativity in love and break-up letters $(\mathrm{L}=$ love letters; B-U = break-up letters).

\section{Love Letters}

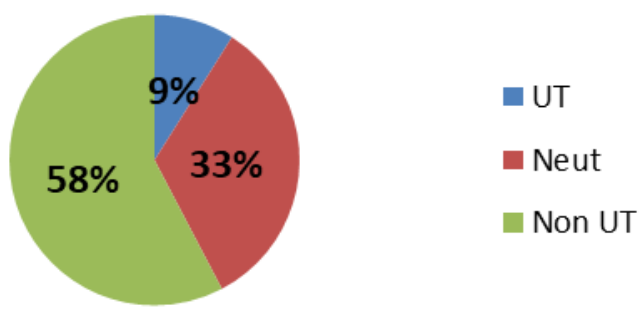

Figure 12: (Non-)utilitarianism in L letters. UT = utilitarian; Neut = neuter; Non UT = non-utilitarian.

\subsubsection{Data from focus group interviews}

To respect the interviewees' privacy, as they were revealing even very personal aspects of their lives, we decided not to collect the notes taken by the interviewers and their fellow students. However, we instructed the participants to take inspiration from their interview notes when they had to gather insights to write on post-its in the Affinity mapping phase. So we can say that data from the Focus

\section{Break-up Letters}

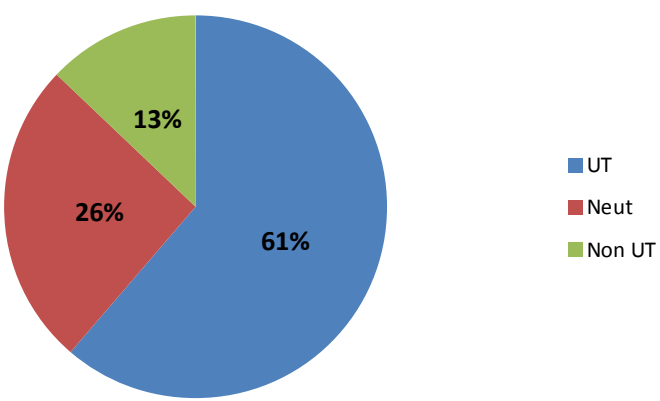

Figure 13: (Non-)utilitarianism in B-U letters.

\section{Love and Break-up Letters}

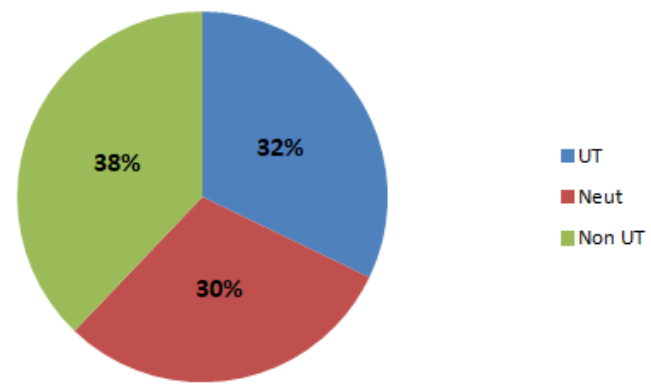

Figure 14: (Non-)utilitarianism in L and B-U letters taken together.

group interviews were indirectly gathered this way to be employed later, together with the bulk of data from the Affinity mapping, to investigate $R Q 1$.

\subsubsection{Data from affinity mapping and prioritizing}

As anticipated in the previous Section, we designed the Affinity mapping and prioritizing activities to re-activate on the level of DDs 2-4 the hermeneutical competencies of empathy and creativity within the process of understanding through contextualizing. The specific strength of Affinity mapping and prioritizing is that it fosters the activation of those competencies in a shared hermeneutical process where each participant's point of view is acknowledged, which enables students' experience of a 'dialogical space' (as meant in Culén \& Gasparini, 2019; s. again in Discussion). In this light, we did not need to quantify evidence for empathy, creativity and (non-)utilitarianism in the data from this workshop phase. Evidence for empathy and creativity (whether in a non-utilitarian or utilitarian perspective) can be easily found in the post-its from each of the four groups (s. full list in The Online depository): all groups demanded for more workshops, more 


\begin{tabular}{|c|c|c|c|c|c|}
\hline & Main Concepts & Critical Points & & Main Concepts & Critical Points \\
\hline \multirow[t]{7}{*}{ Group 1} & $\begin{array}{l}\text { DIDACTIC SUPPORT } \\
\text { tot. } 10 \text { post-its }\end{array}$ & & \multirow[t]{7}{*}{ Group 2} & $\begin{array}{l}\text { PROPOSALS } \\
\text { tot. } 20 \text { post-its }\end{array}$ & $\begin{array}{l}\text { MORE EXAM } \\
\text { DATES }\end{array}$ \\
\hline & $\begin{array}{l}\text { LOGISTICS } \\
\text { tot. } 7 \text { post-its }\end{array}$ & & & $\begin{array}{l}\text { UNIURB } \\
\text { PROBLEMS } \\
\text { tot. } 5 \text { post-its }\end{array}$ & \\
\hline & $\begin{array}{l}\text { ECONOMY, COSTS } \\
\text { tot. } 7 \text { post-its }\end{array}$ & $\begin{array}{l}\text { CHEAPER AND } \\
\text { MORE } \\
\text { FREQUENT } \\
\text { PUBLIC } \\
\text { TRANSPORT }\end{array}$ & & $\begin{array}{l}\text { TOWN PROBLEMS } \\
\text { tot. } 11 \text { post-its }\end{array}$ & TRANSPORT \\
\hline & $\begin{array}{l}\text { DIDACTIC } \\
\text { ORGANIZATION } \\
\text { tot. } 12 \text { post-its } \\
\end{array}$ & $\begin{array}{l}\text { TOO MUCH } \\
\text { LESSON } \\
\text { OVERLAP }\end{array}$ & & $\begin{array}{l}\text { DIDACTIC ISSUES } \\
\text { tot. } 8 \text { post-its }\end{array}$ & $\begin{array}{l}\text { DIDACTIC } \\
\text { ORGANIZATION }\end{array}$ \\
\hline & $\begin{array}{l}\text { BUREAUCRACY AND } \\
\text { SECRETARIAT } \\
\text { tot. } 11 \text { post-its }\end{array}$ & $\begin{array}{l}\text { OVERCROWDED } \\
\text { SECRETARIAT } \\
\text { AND } \\
\text { INCOMPLETE } \\
\text { INFORMATION }\end{array}$ & & $\begin{array}{l}\text { PSYCHO-PHYSICAL } \\
\text { ISSUES } \\
\text { tot. } 4 \text { post-its }\end{array}$ & \\
\hline & $\begin{array}{l}\text { TECHNOLOGICAL } \\
\text { SUPPORT } \\
\text { tot. } 5 \text { post-its }\end{array}$ & & & $\begin{array}{l}\text { THE } \\
\text { HEART CORNER } \\
\text { tot. } 8 \text { post-its }\end{array}$ & \\
\hline & Main Concepts & Critical Points & & Main Concepts & Critical Points \\
\hline \multirow[t]{4}{*}{ Group 3} & $\begin{array}{l}\text { ERASMUS AND } \\
\text { CONTACTS ABROAD } \\
\text { tot. } 19 \text { post-its }\end{array}$ & $\begin{array}{l}\text { MORE } \\
\text { CONTACTS } \\
\text { ABROAD }\end{array}$ & \multirow[t]{4}{*}{ Group 4} & $\begin{array}{l}\text { [PERSONAL] } \\
\text { GROWTH } \\
\text { tot. } 6 \text { post-its }\end{array}$ & \\
\hline & $\begin{array}{l}\text { SCHEDULES } \\
\text { tot. } 12 \text { post-its }\end{array}$ & $\begin{array}{l}\text { LESS } \\
\text { LESSON } \\
\text { OVERLAP }\end{array}$ & & $\begin{array}{l}\text { UNIVERSITY } \\
\text { ORGANIZATION } \\
\text { ISSUES } \\
\text { tot. } 16 \text { post-its }\end{array}$ & $\begin{array}{l}\text { LESSON } \\
\text { SCHEDULES }\end{array}$ \\
\hline & $\begin{array}{l}\text { (NO TITLE) } \\
\text { [facilities, } \\
\text { scholarships, } \\
\text { secretariat and } \\
\text { didactics] } \\
\text { tot. } 27 \text { post-its }\end{array}$ & & & $\begin{array}{l}\text { PERSONAL } \\
\text { ORGANIZATION } \\
\text { ISSUES } \\
\text { tot. } 9 \text { post-its }\end{array}$ & $\begin{array}{l}\text { ORGANIZATION, } \\
\text { TRANSPORT }\end{array}$ \\
\hline & $\begin{array}{l}\text { TRANSPORT } \\
\text { tot. } 7 \text { post-its }\end{array}$ & $\begin{array}{l}\text { IMPROVE } \\
\text { TRANSPORT }\end{array}$ & & $\begin{array}{l}\text { POSITIVE } \\
\text { EXPERIENCES AT } \\
\text { UNIVERSITY } \\
\text { tot. } 7 \text { post-its }\end{array}$ & \\
\hline
\end{tabular}

Figure 15: Affinity mapping: thematic groups with critical points (for the full list of the post-its s. Online depository). 
teamwork, more personal interaction between students and teachers, more interactive didactics, more common rooms (lounges) for students, more common activities with Erasmus and other international students, more support for Erasmus, more intercultural curricular and extracurricular activities (also involving the town), more 'passion-igniting' activities, more student-empowering initiatives, more psychological and vocational support. However, a datum emerged from the post-its that we could at first not properly evaluate. When asked to point at "the two most important challenges and needs for all [members of each group]" in relation to the participants' present-day possibilities and future goals, almost all groups selected within the thematic clusters of their affinity maps three critical points instead of two, most of which address basic every-day needs (see for instance transport and course schedule issues in Figure 15).

If compared with data from the love and break-up letters, a fundamental difference emerges in spite of surface analogies (such as complaints about lesson overlap): on one side, the letters place the Uniurb experience in the bigger picture of an individual's existence. They mostly depict it as a step in a student's life path, thus evaluating Uniurb and expressing needs and desires in the perspective of a student's future. On the other side, students in this Affinity mapping and prioritizing phase responded to the task of indicating 'present challenges/ possibilities' and 'future goals' through critical points that seem determined by the material constraints of the students' immediate present. Here, a reference to future perspectives such as professional planning and the role Uniurb might have for the students' future achievements seems, at least at a superficial glimpse, to be blended out. The obvious question of why workshop participants blended this out in spite of the explicit question we had posed to them at the beginning of this phase cannot be thoroughly investigated here, as this would lead us offtopic. However, we might attempt at an answer by pointing at our interdisciplinary framework as well as at the nature of DT, where one elaborative force, abductive reasoning, has allowed a redefinition of the problem. As we argue, lacking reference to future plans or career-fostering initiatives in student responses to our task (“... Which needs should Uniurb cover in future to help you achieve your goals?") should not be interpreted as a 'resigning response' by our students to present-day Italian economic stagnation. Data from Session One and Session Two of the workshop give no evidence for students' pessimistic mindset. Rather, such a difference between data from the letters and from the critical points might be a cue for the success of our interdisciplinary framework joining DT with the humanities: in this Affinity mapping and prioritizing phase, students no longer responded to the workshop tasks primarily as individuals. They did it as a social body: as the community of the students, whose horizon it is to make, in every respect, the best out of their three- to fiveyear-long experience at Uniurb. In this context, good lesson scheduling, as 'present-oriented' as it may seem, turns out as a significant investment for the future: as the letters had revealed, students want to be able to attend all the lessons of their syllabus because, first, they find them inspiring, second, because by interacting with teachers and fellow students they learn the stuff better than through selfstudy, third, because they can more easily pass the exam after having attended the lessons than after self-study. Thus, in the urgent request for less schedule overlap, both personal-existential, social, and vocational-professional development are addressed. In this perspective, also the participants' demand for a more efficient and cheaper (thus equalitarian) public transport system is meant to benefit the student community as a whole, including many Uniurb students with no private cars or with jobless parents. Our aim of turning the single workshop participants into a polyphony where each single voice, while still recognizable, concurs to one harmonic whole, seems to have been achieved already in this phase. Testing how aware students were of this, was one of our aims in the following phases.

\subsubsection{Data from prototyping with 'Fast ideas'}

Here each student had to conceive within ten minutes at least six ideas/proposals addressing the critical points of their group. One striking element emerges from their ideas (s. full list in the Online depository): even though all four groups shared the same few critical points (transports, lesson overlap, didactic organization, overall organization, contacts with abroad), the range of ideas and proposals developed out of them went well beyond their scope. If one looks at the ideas, all groups proposed some initiatives that, even when conceived for the benefit of students themselves, presuppose the students' proactive contribution to better the state of the university and/or to empower the Urbino territory. To take one instance from each of the groups, proposals range from "organizing cooperative experiential learning initiatives to foster learning through activities that empower the territory" to "initiating [students' and citizens'] volunteering services to meet the students' needs (tutoring, cleaning streets from snow, etc.)", from "reactivating the railway connection to Urbino " to 
"starting student-driven cafés / lounges / multifunctional halls by using buildings in disuse in the town-center where students can study, relax, meet, and organize cultural events". Even more curriculum-close proposals seem to arise from the students' wish to make sense of their presence at Uniurb as a co-creation enterprise: for instance, when they propose to "organize regular meetings between students and teachers or between students themselves to identify problems and propose solutions" or "[Uniurb/employers] might pay students working in internships by improving services for [all] students". There seems to be barely evidence for a consumer mindset in the 'fast ideas'. Thus, data from this phase suggest that the competencies acquired in the philology lessons on the level of DDs 2-5 in terms of understanding through contextualizing, empathy, creativity, and the capacity to distinguish and choose between a non-utilitarian and utilitarian mindset (especially when the latter is flattened to a mere consumer attitude), have been properly re-activated in this DT setting and oriented towards relational agency. This provides evidence also for RQ2: an image of a student comes to light who is willing to commit her/himself to the common good beside their own.

\subsubsection{Data from $A / B / C$ idea sorting and 'best idea' selection}

In each group, the students had now the task to classify their fast ideas into A, B, C ideas according to their complexity and to time and other resources requested to make them real. The judgment about where to place each idea was theirs. Then they chose out of each group one 'best idea' (again judging by themselves what 'best' should mean) and they presented it to the plenum while trying to convince them that theirs was really a great idea. The four 'best ideas' were: including transport service in university fees (classified as A); paying students for their work in internships (C); starting a student-managed one-to-one tutoring service between Uniurb students and international students (A); organizing a contest where students propose ideas for innovation in Uniurb administration and governance (A).

The evaluation of "including transport service in university fees" as an A (= easy to make real) idea made us suspect that the workshop participants' efforts to contextualize their ideas in the territory was not supported by a concrete knowledge of the challenges of problemsolving when different stakeholders have to interact with each other: this might be a serious obstacle to effective student participation in formal bodies of university governance. So, we hoped to have the opportunity to tackle this issue in the user journey of Session Two.

\subsubsection{Data from feedback}

Participants' feedback was collected on four large sheets of paper, one for each group (s. Online depository). This concluding phase of Session One of the workshop, again, provides evidence that our joint DT-humanities approach fosters SCL (= RQ1) as well as a proactive attitude both as an individual and as part of a community, which is a positive response to $R Q 2$. Coherence with SCL is suggested by comments such as "stimulating" (from all four groups), "illuminating”, “(very) interesting”, "Many solutions are possible", "functional", "productive", "constructive”, "funny", "colorful”, "creative”. Remarks are there that also point more directly at a participating attitude: "Change”, "hope”, "innovation", "revolution”, "discussion", "exchange of ideas", "It was a true pleasure to participate", "Useful and effective, but only if the ideas that have emerged will really be taken into consideration", "It enriches one's heart and it allows one to have a voice in the matter! To be recommended to all - young and [here word not readable] adults!”

\subsection{Data from Session Two}

As for data from Session Two, the participants' behaviors during their user journeys also provide positive evidence for both our research questions. As described in 4.2, the participants selected two ideas out of their four 'best ones' from Session One (s. videos in the Online Depository):

User journey of group A: Find financial resources to pay for student apprenticeships. User journey of group B: Find a way to strongly reduce transport fees and include them within university fees.

We then explained to them what a user journey is and pointed at the importance, to their aims, of the notions of 'touch points', 'critical moments', and 'magic moments'. We encouraged them to set their imagination free (visual thinking). Before they started, we also drew their attention to the fact that while designing their user journeys they would have to play both the role of a design thinker and of their addressee, as they would be developing two ideas conceived by students (= themselves) for students. We also made them aware that in order to anticipate in their minds the process that leads, for instance, to finding a way to reduce bus fees and include them in university fees, they would also had to imagine 'the backstage' of 
their user journey, that is, the complex setting involving all relevant stakeholders and resources, and take on also their points of view. So, at least three perspectives should cohabitate in their minds while designing a user journey: the design thinkers', the students', and the (numerous) other stakeholders' (e.g. the Region Marche, the Urbino municipality, funding institutions, law-givers, etc.), all interacting with each other. This corresponds on one side to the 'cognitive side' of empathy in philology and DT, on the other side to the real interaction that goes on along the steps of institutional decision-making in some of the formal bodies of $\mathrm{HE}$ where student representatives participate. This makes the user journey template a very effective tool with which students may train their skills to represent their community in those bodies. An anecdote from that morning should illustrate how Session Two worked. In the middle phase of designing, students from group B were sticking in a 'critical moment': "What if the institutions will not take our requests seriously? What if they will leave our letters unanswered?” The Uniurb-based author invited them to think analogically by telling them a story from her own study time 'in the glorious Era of student fights before the fall of the Berlin wall and before the internet': how 'her' representatives succeeded in persuading the university president of her alma mater not to increase university fees by simply organizing student marches blocking all access routes to the town center. The whole protest had been organized in students assemblies, on the telephone, and with self-stamped handouts. After hearing this story, students decided to solve their 'critical moment' by including a huge social media campaign into the user journey. Such is the power of story-telling.

\subsection{Data from feedback from Session Two}

FeedbackfromSessionTwo(s. Onlinedepository)resembles that from Session one: comments such as "creative", "funny", "engaging”, "challenging”, "I can use it in my life" point at our joint approach as an effective framework for SCL; and notes such as "Hopefully will our project become reality!” indicate students' care for their fellow students. A comment was left that had no antecedent in feedback to Session one: "Collaborating for the community". Here the students' awareness to be a community - not a market target group - whose members collaborate for the common good is made explicit for the first time. Such awareness that our joint approach enhances community has become even deeper after one year, according to new feedback given to us by the workshop participants in spring 2019 (s. texts in Online depository).

\subsection{Discussion of the evidence}

Our project started to investigate the issue of how to foster student participation in HE both in its formal area of participating in institutional bodies of governance, and in its informal area of SCL. Our investigation took place to investigate the reasons for insufficient student participation in university governance in many EHEA countries (including Italy and Uniurb), and to provide a means to counteract such a decreasing trend. We decided to engage in an interdisciplinary research process that would hopefully lead us to create an effective framework within which students might learn and train their participating and governing skills while reflecting on who they are and what role they want to play in their educational enterprise. As we are both committed to a democratic vision of $\mathrm{HE}$ as a common good with multiple personal and social aims, we have developed a joint approach between DT and the humanities which, as findings from data analysis seem to confirm, has enabled us to effectively enhance students' confidence in their ability to affect HE policies. We have thus created a learning space where students are motivated and encouraged to behave as proactive partners in HE institutions both as individuals and as a community.

Our participants' high engagement in our experiment seems to relativize some psycho-sociological approaches to seemingly 'passive' students' attitudes in Italy which try to explain them in terms of pessimism due to economic stagnation or chronically hyper-protective families: if this were the case, they would not have enrolled in the workshop at all. Attending it was optional. As we suggest, the issue has to be investigated in the context of the 'managerial turn' in HE, with its view of students as consumers displaying their collective role in service rating and quality assurance, colliding with the earlier vision of $\mathrm{HE}$ as a collegiate enterprise, with its view of students as an educationalpolitical collective subject displaying their collective role in ideological negotiations in formal governance bodies. Some notes from feedback taken in May 2019, one year after the workshop, provide in our view a key cue to comprehend the stakes behind students' lacking participation in HE. One participant writes (literal quotation): "From the moment I started my academic career till now I didn't find a community where people would meet to express their personal view about the institution sharing ideas to build a stronger and fairer education system. Hence I have never experienced the community life as a student and this affected my view on higher education since I thought university and policymakers would not consider my feedback and suggestions to improve themselves. I think that this workshop was a step towards the 
modernization of the university - and of the humanities in particular - which nowadays is struggling to find its propose in our technology-driven society." Similarly, another participant reminds (again, literal quotation): "Once I felt like my needs and perceptions as a student were not important, somehow 'ignored'. But, during the workshop, this changed: my voice, with my colleagues' voices, was heard. We were together, we were now 'proactive' students, having fun and proposing our ideas to improve Uniurb, for us and for future generations." The key information here, as in many other comments from feedback taken in May 2019, is that participants in our workshop felt listened to and taken seriously for the first time at Uniurb. The second key information is that they felt so because in the workshop they were feeling part of a community where every point of view was equally acknowledged. It was precisely this feeling of being taken seriously as an individual in a community that encouraged them to raise their voice and make proposals (the comments in the 2019 feedback are illuminating in this respect, s. full texts in the Online depository). In light of these students' words, the issue becomes very clear. Weakness does not lie in the students supposed 'passivity': it lies in the present HE system, which offers no real space for dialogue. In the 'managerial' vision of HE, students' voices are recorded in rating questionnaires with pre-guided questions. In the 'collegiate' vision, students' voices are spoken in formal bodies with little chance of being listened to (they usually may not vote or veto, only advise). Both models draw ultimately on a utilitarian, conflict-based notion of power, with students sitting on the lighter side of the balance. However, conflict is not intrinsic in power. As the Latin origin of this word reveals, power means essentially 'being able to, being in the condition of'. In this sense, the place of true empowerment is community, precisely in its being a space where everybody's voice is acknowledged and enhanced in an interplay of mutual listening and talking to. This is why our workshop granted students this experience 'for the first time': it was based on dialogue. DT in its nature as a 'dialogical space' (s. Culén \& Gasparini, 2019), and, as we may argue now, as a 'dialogical learning space', is enriched by humanities' millenary tradition of dialogue in that non-utilitarian perspective which acknowledges a human being as an end in itself; on their side, humanities are enriched by DT as a dialogical space where mutual respect leads to hands-on and problem-tackling enthusiasm.

\section{Conclusions and outlook}

This study has some limitations. The first one is that it cannot explore all concurring reasons for insufficient student participation in governance exhaustively enough: a thorough assessment of social, educational, and mentality factors, beside those investigated here, will be needed to effectively tackle the question. However, the present case-study has framed the question and provided a useful starting point to develop a multi-level investigation.

A second limitation is that the workshop was too short to display all the potentials of our joint approach. Ethnographic research, for instance, was limited to the focus group interviews; ideating and prototyping were 'pressed together'. We intended that students might learn to think as designers, thus approaching reality with a mode of knowledge new to them; unfortunately, we had few hours at our disposal. However, the positive results have encouraged us to propose DT again by using this 'joint DT-humanities template' in a 15-hour initiative in the 2020 philology course. Data from the present case-study will serve as a control group. A third limitation is that our experiment addressed only humanities students. Its outcomes allow almost no inference on the issue whether students from other Uniurb curricula (e.g. from law or informatics) perceive themselves as customers and Uniurb as a service-providing institution: in other words, whether the pressures of the modernization agenda of the European Commission on the EHEA and the national ministries for education and research have already been internalized by nonhumanities students. However, we have recently initiated a project involving students from all study programs at Uniurb. Some student representatives from the Uniurb based author's department are designing with us a DT collaboratory on the basis of the approach developed in this case-study. In the long term, the collaboratory should be driven by the representatives themselves. Thus, initiatives by students (for instance those from our user journey, and others) might be developed (also by involving other stakeholders) into well-designed projects to be proposed by student representatives to the formal and informal bodies of Uniurb governance.

In this collaboratory, workshops linking DT with the epistemologies of the other disciplines will allow more reliable evidence on the issue of students' self-perception and on the nature of their relationship to a HE institution such as Uniurb. Such an issue has serious implications for the future of DT. If DT is willing to thrive as a learning approach in 
educational settings, the question whether students perceive themselves as customers or citizen partners delves into the vital core of DT: empathy, with its link to creative confidence. If humanities students do see and express themselves as equal partners in the collegiate endeavour of HE, a design thinker who addressed them as customers and their teachers as service-providers (or content-transmitters) instead of educators, would commit a gross lack of empathy towards them, and any attempt from his/her side to help them design university would fail. Happily, DT shares with humanities that interdisciplinary epistemology which arises from the fact that they both focus on questions "that no single discipline can provide a complete answer to on its own." (Szostak, 2019, Manifesto of interdisciplinarity, "Defining"). Consequently, when addressing a human being, DT can greatly benefit from the humanities' approach to human nature and redefine humanity according to the changing contexts of DT applications by taking into account the fact that we always perceive ourselves as 'more' and bear within us a never-ending bundle of existential yearnings - even when we enter a situation with the role of users. From its side, the humanities can greatly benefit from DT to integrate the students' standpoints into scholarly discussion on university governance, and to enhance students' agency and participation in any kind of HE governance policies, not only in those fields, such as quality assurance, that do not question the establishment's preeminence on choices. Students' forward-looking mindset should also affect governance where substantial innovation is at stake, such as long-term strategies in formal decision bodies. If applied on a larger scale, DT will give Uniurb students the opportunity to self-lead taskforces to assist their representatives in all decision-making contexts where students are required to be, and help design 'their' university.

\section{References}

Almendra, R. \& Christiaans, H. (2013). 'Design thinking': the Emperor's new suit. Design Principles and Practices: An International Journal: Annual Review. Volume 6. Champain, Illinois: Common Ground, 1-19. http:// designprinciplesandpractices.com/.

Ast, F. (1808). Grundlinien der Grammatik, Hermeneutik und Kritik. Landshut: Jos. Thomann.

Battarbee, K., Fulton Suri, J. \& Gibbs Howard, S. (2015). Empathy on the edge. Scaling and sustaining a human-centered approach in the evolving practice of design. Case Study. Harvard Business Review.
Barsalou, L.W. (2017). Define design thinking. she ji The Journal of Design, Economics, and Innovation 3 (2), pp. 102-105. https:// doi.org/10.1016/j.sheji.2017.10.007

Boden, M. A. (2004). The creative mind: Myths and mechanisms, London: Routledge.

Bracco, M. (2005). Empatia e neuroni specchio. Una riflessione fenomenologica ed etica. Comprendre, 15, 33-53. Retrieved from https://www.in-formazione-psicologia.com/braccomirror.pdf

Braun, E., Moreland, J., Sanders, E. \& Gill, C. (2014). Designer in design thinking. International Conference on Engineering and Product Design Education. 4 \& 5 September 2014, University of Twente, The Netherlands.

Brauer, J. (2013). Empathie und historische Alteritätserfahrung, in: Brauer, J. \& Lücke, M. (Hg.) (2013). Emotionen, Geschichte und historisches Lernen. Geschichtsdidaktische und Geschichtskulturelle Perspektiven. Göttingen: V\&R Unipress, 75-92.

Bremer, K. \& Wirth, U. (2010). Die philologische Frage. Kulturwissenschaftliche Perspektiven auf die Theoriegeschichte der Philologie. In: Texte zur modernen Philologie. Hg. von K. Bremer und U. Wirth. Stuttgart: Reclam, 2010, S. 10-47.

Brown, T. (2008). Design thinking. Harvard Business Review, June, 84-92.

Brown, T. (2009). Change by design. New York: HarperCollins.

Buchanan, R. (1992). Wicked problems in design thinking. Design Issues, 8 (2), pp. 5-21.

Burdick, A. \& Willis, H. (2011). Digital learning, digital scholarship and design thinking. Design Studies, 32, pp. 546-556. doi:10.1016/j.destud.2011.07.005

Callahan, E. (2018) Cross-Cultural Empathy: Learning About Diverse Users in Design Thinking Process. In: Stephanidis C. (eds) HCl International 2018 - Posters\&\#39; Extended Abstracts. $\mathrm{HCl}$ 2018. Communications in Computer and Information Science, vol 850. Springer, Cham, pp. 236-240. DOI https://doi. org/10.1007/978-3-319-92270-6_32

Camacho, M. (2018). An integrative model of design thinking. 21st DMI: Academic Design Management Conference. Next Wave, London, UK, 1-2 August, 2018, 627-641.

Canfora, L. (2008). Filologia e libertà. La più eversiva delle discipline, 㚿indipendenza di pensiero e il diritto alla verità. Milano: Mondadori.

Coyne, R. \& Snodgrass, A. (1991). Is designing mysterious? Challenging the dual knowledge thesis. Design Studies 12 (3), pp. 124-131.

Cropley, A. (2006). In Praise of Convergent Thinking. Creativity Research Journal, 18(3), 391-404. https://doi.org/10.1207/ s15326934crj1803_13

Cross, N. (2001). Designerly ways of knowing: design discipline versus design science. Design Issues, 17 (3), pp. 49-55.

Culén, A. L. \& Gasparini, A. A. (2019). STEAM education: Why learn design thinking? In: Babaci-Wilhite, Z. (ed.). Promoting language and STEAM as human rights in education: science, technology, engineering, arts and mathematics, Singapore: Springer Nature, pp. 91-118.

CUN (2017). Guida alla scrittura degli ordinamenti didattici (A.A. 18/19). 09 novembre 2017 (versione aggiornata al 15 dicembre 2017). 
Dewey, J. (1929). The quest for certainty: a study of the relation of knowledge and action. New York: Minton, Balch \& Company.

Diethelm, J. (2016). De-colonizing design thinking. she ji The Journal of Design, Economics, and Innovation, 2 (2), pp. 166-172.

Diethelm, J. (2017). Embodied design thinking. Pp. 1-14 . Retrieved from https://www.academia.edu/35214088/Embodied_ Design_Thinking

Dorst, K. (2006). Design problems and design paradoxes. Design Issues, 22(3), 4-17.

Dorst, K. (2011). The core of 'design thinking' and its application. Design Studies, 32, pp. 521-532.

Dilthey, W. (1900). Die Entstehung der Hermeneutik. In G. Misch (Hg.) (1924) Wilhelm Diltheys Gesammelte Schriften. V. Bd.: Die Geistige Welt. Einleitung in die Philosophie des Lebens. Erste Hälfte: Abhandlungen zur Grundlegung der Geisteswissenschaften. Berlin: B. G. Teubner.

Dym, C. L., Agogino, A. M., Eris, O., Frey, D. D. \& Leifer, L. J. (2005). Engineering design thinking, teaching, and learning. Journal of Engineering Education, pp. 103-120.

ECTS Users' Guide (2015). Luxembourg: Publications Office of the European Union. doi:10.2766/87192

EHEA (2018). Paris Communiqué, Appendix III. Retrieved From http:// www.ehea.info/Upload/document/ministerial_declarations/ EHEAParis2018_Communique_AppendixIII_952778.pdf

ESG (2015). Standards and Guidelines for Quality Assurance in the European Higher Education Area. Brussel, Belgium. Retrieved from https://enqa.eu/wp-content/uploads/2015/11/ESG_2015. pdf

ESU (2015). Bologna with students' eyes. Overview on studentcentred learning in higher education in Europe. Research study by European Students' Union. Brussels. Retrieved from https:// www.esu-online.org/wp-content/uploads/2016/07/Overviewon-Student-Centred-Learning-in-Higher-Education-in-Europe. pdf

ESU (2018). Bologna with students' eyes. The final countdown. By European Students' Union. Retrieved from https://www.esuonline.org/wp-content/uploads/2018/06/BWSE-2018_web_ Pages.pdf

Frodeman, R. \& Mitcham, C. (2007). New directions in interdisciplinarity: broad, deep, and critical. Bullettin of Science, Technology \& Society 27 (6), 506-514. https://doi. org $/ 10.1177 / 0270467607308284$

Gasparini, A. A, (2014). The value of empathy in Design Thinking. In: Innovation in $\mathrm{HCl}$ : What can we learn from Design Thinking? Workshop. In conjunction with NORDICHI 2014, Helsinki, Finland.

Gasparini, A. A. (2015). Perspective and use of empathy in Design Thinking. In L. Miller \& A. Culén (eds.), ACHI 2015: The Eighth International Conference on Advances in Computer-Human Interactions. February 22 - 27, Lisbon, Portugal. Wilmington, DE: IARIA, pp. 49-54.

Gasparini, A. A. \& Culén, A. L. (2017). Temporality and innovation in digital humanities: the case of papyri from Tebtunis. Interaction Design and Architecture(s) Journal, 34, pp. 161-184.

Goldschmidt, G. (2017). Design thinking: a method or a gateway into design cognition? she ji. The Journal of Design, Economics, and Innovation, 3 (2), pp. 107-112.

Harmsen, R. (2015) Future Scenarios for the European Higher Education Area: Exploring the Possibilities of "Experimentalist
Governance”. In: Curaj A., Matei L., Pricopie R., Salmi J. \& Scott P. (eds). The European Higher Education Area. Springer, Cham Haeffner, G. (2005): Philosophische Anthropologie. 4., überarbeitete und ergänzte Auflage. Stuttgart; Berlin; Köln: Kohlhammer.

Henriksen, D. (2017). Creating STEAM with design thinking: beyond STEM and arts integration. The STEAM Journal, 3 (1), article 11. DOI: 10.5642 /steam.20170301.11

Henriksen, D., Richardson, C. \& Mehta, R. (2017). Design thinking: a creative approach to educational problems of practice. Thinking Skills and Creativity, 26, pp. 140-153. https://doi. org/10.1016/j.tsc.2017.10.001

Illeris, K. (2018). An overview of the history of learning theory. European Journal of Education, 53, 86-101. DOI: 10.1111/ ejed.12265

Jacob, J. (2018). Intersections in design thinking and art thinking: towards interdisciplinary innovation. Creativity. Theories Research - Applications, 5(1), 4-25.

Jansen, E. \& Goedhart, M. (2010). (Inter)disciplinary Dublin descriptors? Implementation of the Bologna process in a Dutch university. Interdisciplinary Higher Education: Perspectives and Practicalities. International Perspectives on Higher Education Research, 5, 115-131.

Johansson-Sköldberg, U., Woodilla, J. \& Çetinkaya, M. (2013). Design Thinking: Past, Present and Possible Futures. Creativity and Innovation Management, 22 (2), pp. 121-146.

Kelley, T, \& Kelley, D. (2013). Creative confidence. Unleashing the creative potential within us all. New York: Crown Business.

Kimbell, L. (2011). Rethinking design thinking: part one. Design and Culture, 3 (3), pp 285-306.

Kimbell, L. (2012). Rethinking design thinking: part two. Design and Culture, 4 ( 2), pp. 129-148.

Klemenčič, M. (2012), The changing conceptions of student participation in HE governance in the EHEA. In A. Curaj, Sir P. Scott, L. Vlasceanu \& L. Wilson (eds.) European higher education at the crossroads - between the Bologna Process and national reforms, Heidelberg: Springer, pp. 631-653.

Klemenčič, M. (2015). Student involvement in quality enhancement, in: J. Huisman, H. De Boer, D. Dill \& M. Souto-Otero (Eds). The handbook of Higher Education policy and governance, London: Palgrave Macmillan, pp. 526-543.

Klemenčič, M. (2017). From student engagement to student agency: conceptual considerations of European policies on studentcentered learning in higher education. Special issue: Critical and alternative perspectives on student engagement, eds. Bruce Macfarlane and Michael Tomlinson. Higher Education Policy, 30 (1), pp. 69-85.

Koh, J. H. L., Chai, C.S., Wong, B. \& Hong, H. Y. (2015). Design thinking for education. Conceptions and applications in teaching and learning. Singapore: Springer.

Kolko, J. (2015). Design Thinking Comes of Age. Harvard Business Review, 93(5), pp. 66-71. Retrieved from https://hbr. org/2015/09/design-thinking-comes-of-age

Köppen, E. \& Meinel, C. (2015). Empathy via design thinking: creation of sense and knowledge. In: Plattner, H., Meinel, C. \& Leifer, L. (eds.). Design thinking research - building innovators. Berlin, Heidelberg: Springer, pp. 15-28. https://doi. org/10.1007/978-3-319-06823-7_2 
Kurokava, T. (2013). Design thinking education at universities and graduate schools. Quarterly Review, 46, pp. 50-62.

Liddel, H.G. \& Scott, R. (1901). A Greek-English Lexicon. Eighth edition, revised throughout. New York et al.: American Book Company.

Liedtka, J. (2015). Perspective: Linking Design Thinking with Innovation Outcomes through Cognitive Bias Reduction. The Journal of Product Innovation Management, 32 (6), 925-938.

Lindgaard, K. \& Wesselius, H. (2017). Once more, with feeling: design thinking and embodied cognition. she ji The Journal of Design, Economics, and Innovation, 3 (2), pp. 83-92.

Lipka, L. (2002). English lexicology. Lexical structure, word semantics and word-formation. Tübingen: Narr.

Lor, R. (2017). Design thinking in education: a critical review of literature. IACSSM; ACEP, Conference Proceedings, Bangkok, Thailand, Mai 24-26, 2107, pp. 36-68.

Lyons, J. (1977). Semantics. Volume 1. Cambridge: Cambridge University Press.

Meffert, H., Gazzola, V., den Boer, J. A., Bartels, A. A. J., \& Keysers, C., (2013). Reduced spontaneous but relatively normal deliberate vicarious representations in psychopathy. Brain, 136 (8), pp. 2550-2562.

Montanari, F. (2013), Vocabolario della lingua greca. Con la collaborazione di Ivan Galofaro e Daniela Manetti. Terza edizione. Torino: Loescher.

New, S. \& Kimbell, L. (2013). Chimps, designers, consultants and empathy: a "theory of mind" for service design. 2nd Cambridge Academic Design Management Conference, 4 - 5 September 2013, pp. 1-14. Retrieved from http://www.lucykimbell.com/ stuff/New_Kimbell_Empathy_2013.pdf

Norman, D. (2013). The design of everyday things. Revised and expanded edition. NY: Basic Books.

Noweski, C., Scheer, A., Büttner, N., von Thienen, J., Erdmann, J. \& Meinel, C. (2012). Towards a paradigm shift in education practice: developing twenty-first century skills with design thinking. In: H. Plattner, C. Meinel \& L. Leifer (eds.). Design thinking research - measuring performance in context. Berlin, Heidelberg: Springer, pp. 71-94. https://doi.org/10.1007/9783-642-31991-4_5.

Nowak, M. (2011). The Complicated History of Einfühlung. Argument: Biannual Philosophical Journal, 1 (2), pp. 301-326.

Nussbaum, M. (2001). Upheavals of thought. The intelligence of emotions, Cambridge: Cambridge University Press.

Nussbaum, M. (2011). Creating capabilities: the human development approach. Cambridge (MA) et al.: The Belknap Press of Harvard University Press.

Owen, C. (2007). Design thinking: notes on its nature and use. Design Research Quarterly, 2, pp. 16-27.

Peels, R. (2018). Epistemic values in the humanities and in the sciences. History of Humanities, 3 (1), pp. 89-111.

Pollock, S. (2016). Philology and freedom. Philological Encounters, 1,14-30. Retrieved from http://www.columbia.edu/cu/mesaas/ faculty/directory/pollock_pub/Philology\%20and\%20Freedom. pdf

Poser, H. (2012). Wissenschaftstheorie. Eine philosophische Einführung. Zweite, überarbeite und erweiterte Auflage. Stuttgart: Reclam.

Poulsen, S. B. \& Thøgersen, U. (2011). Embodied design thinking: a phenomenological perspective, CoDesign, 7 (1), pp. 29-44, DOI: 10.1080/15710882.2011.563313
QF-EHEA 2005 (February 2005). A Framework for Qualifications of the European Higher Education Area. Bologna Working Group on Qualifications Frameworks. Copenhagen: Ministry of Science, Technology and Innovation. Retrieved from http:// ecahe.eu/w/index.php/Framework_for_Qualifications_of_the_ European_Higher_Education_Area

Rapporto ANVUR, 23/2017: Accreditamento periodico delle Sedi e dei Corsi di Studio: Università degli Studi di Urbino "Carlo Bo". Approvato dal Consiglio Direttivo il 05/09/2017. Doc. 23/2017.Retrieved from http://www.anvur.it/wp-content/ uploads/2017/10/Rapporto\%20ANVUR_URBINO_2016.pdf

Rauth, I., Köppen, E., Jobst, B., \& Meinel, C. (2010). Design Thinking: An Educational Model towards Creative Confidence. In T. Toshiharu \& Y. Nagai (eds.), Proceedings of the 1st International Conference on Design Creativity (ICDC 2010), 29 November - 1 December 2010, Kobe, Japan. Retrieved from https://www. designsociety.org/publication/30267/Design+Thinking\%3A+A $\mathrm{n}+$ Educational+Model+towards+Creative+Confidence

Razzouk, R. \& Shute, V. (2012), What is design thinking and why is it important? Review of Educational Research 82 (3), pp. 330-348.

Recalcati, M. (2018). Ritratti del desiderio. Milano: Raffaello Cortina Editore.

Schön, D. A. (1983). The reflective practitioner: how professionals think in action. New York: Basic Books.

Schwindt, J. P. (Hg.) (2009). Was ist eine philologische Frage? Beiträge zur Erkundung einer theoretischen Einstellung. Berlin: Suhrkamp.

Schwindt, J. P. (2017). Die Theorie der Philologie. Geschichte der Germanistik: Historische Zeitschrift für die Philologien. Hg. von C. König und M. Lepper. Doppelheft 51/52, pp. 74-82.

Sin, C. (2015). Teaching and learning: a journey (in The European Higher Education Area 2015)

Statuto dell回Università degli Studi di Urbino Carlo Bo (2018). Testo in vigore dal 30 novembre 2018. Retrieved from https://www. uniurb.it/ateneo/governance/statuto-e-regolamenti

Sternberg, R. J. \& Lubart, T.I. (1999). The concept of creativity. Prospects and paradigms. In: Handbook of creativity, Cambridge: Cambridge University Press, pp. 3-15.

Szostak, R. (2003), “Comprehensive” curricular reform: providing students with a map of the scholarly enterprise. Journal of General Education, 52 (1), pp. 27-49.

Szostak, R. (2017), Interdisciplinary research as a creative design process, in F. Darbellay, Z. Moody \& T. Lubart (eds.), Creativity, Design Thinking and Interdisciplinarity. Singapore: Springer Nature, pp. 17-34.

Szostak, R. (2019). Manifesto of interdisciplinarity. Retrieved from https://sites.google.com/a/ualberta.ca/manifesto-ofinterdisciplinarity/manifesto-of-interdisciplinarity

Suárez, I. C. \& Suárez, L.V. (2005). The impact of the Bologna process on disciplinization. Comparative report. Retrieved from https://www.york.ac.uk/res/researchintegration/ ComparativeReports/Comparative_Report_Bologna_effect.pdf

Tschimmel, L., Santos, J., Loyens, D., Jacinto, A., Monteiro, R. \& Valença, M. (2015). Research report d-Think. Design thinking applied to education and training. ERASMUS+ KA 2 Strategic Partnerships. Matosinhos: ESAD.

Tschimmel, K. \& Santos, J. (2018), Design thinking applied in higher education: D-Think, a European project for innovating educational systems, in: Carmo, M. (ed.), Education and New Developments 2018 - Proceedings of the National Conference 
on Education and New Developments (END 2018), organized by the World Institute for Advanced Research and Science (WIARS). Lisboa: inScience Press, pp. 209-213.

Verganti, R. (2016). Overcrowded. Designing meaningful products in a world awash with ideas. Cambridge (MA), London (UK): The MIT Press.

Vetlesen, A. J. (1994). Perception, empathy, and judgment. An inquiry into the preconditions of moral performance. University Park: The Pennsylvania State University Press.

Withell, A. \& Haigh, N. (2013). Developing design thinking expertise in higher education. CUMULUS 2013. 2nd International Conference for Design Education Researchers Oslo, 14-17 May 2013. Retrieved from https://openrepository.aut.ac.nz/ handle/10292/6326

Wolf, J. (2012). Kontinuität und Wandel der Philologien. Textarchäologische Studien zur Entstehung der Romanischen Philologie im 19. Jahrhundert. Tübingen: Narr.

Wrigley, C. \& Straker, K. (2017). Design thinking pedagogy: The educational design ladder. Innovations in Education and Teaching International, 54 (4), 374-385. DOI: 10.1080/14703297.2015.1108214, pp. 374-385.

Zara, V. \& Stefani, E. (2017). Istruzione, Attivazione e Accreditamento dei Corsi di Studio. Novità Introdotte da AVA 2.0 e dal DM 987/2016. Roma: Fondazione CRUI. 